\title{
PROBLEMATYKA NARODOWOŚCIOWA RUSI ZAKARPACKIEJ
}

WPROWADZENIE

M ało który z regionów historycznych środkowo-wschodniej Europy ma tyle używanych powszechnie nazw jak Ruś Zakarpacka. Jest to współcześnie jedna z jednostek administracyjnych Ukrainy, która wg urzędowej terminologii ukraińskiej nazywa się obwodem zakarpackim, względnie Zakarpaciem (Закарпаття). W polskiej literaturze geograficzno-historycznej używa się również dla tego wyraźnie wyodrębnionego regionu nazw: Ruś Karpacka, Ruś Podkarpacka, Ruś Przykarpacka, Podkarpacie, Ruś Zakarpacka, Zakarpacie, Ukraina Zakarpacka itp. Nazwa węgierska to Kárpátalja, rumuńska - Transcarpatia, czeska i słowacka - Potkarpatská Rus¹. W okresie międzywojennym w atlasach niemieckich używano nazwy Karpatenrussland, zaś po wojnie Transkarpatien. W terminologii angielskiej to Transcarpathia. Ta różnorodność onomastyczna wynika również z tego, że narody mieszkające po północnej stronie Karpat (Ukraińcy, Polacy) używają pojęcia Zakarpacie, zaś po południowej (Słowacy, Węgrzy) - Podkarpacie. Przy stosowaniu tego nazewnictwa oprócz względów geograficznych mają również wpływ uwarunkowania polityczne. Dla podkreślenia faktu, że region ten stanowi integralną część terytorium ukraińskiego wprowadzono tu w formie rzeczownikowej lub przymiotnikowej słowo „Ukraina” lub „ukraińska”. Nazwy z rdzeniem „Ruś” mogą sugerować rusofilską opcję autora, a nawet wskazują

1 Ruś Zakarpacka w klasycznym dziele angielskiego autora została nazwana „Rutenią” (C.A. Macartney 1937).
Prof. dr hab. Piotr EBERHARDT jest profesorem w Instytucie Geografii i Przestrzennego Zagospodarowania PAN w Warszawie. p.ebe@twarda.pan.pl 


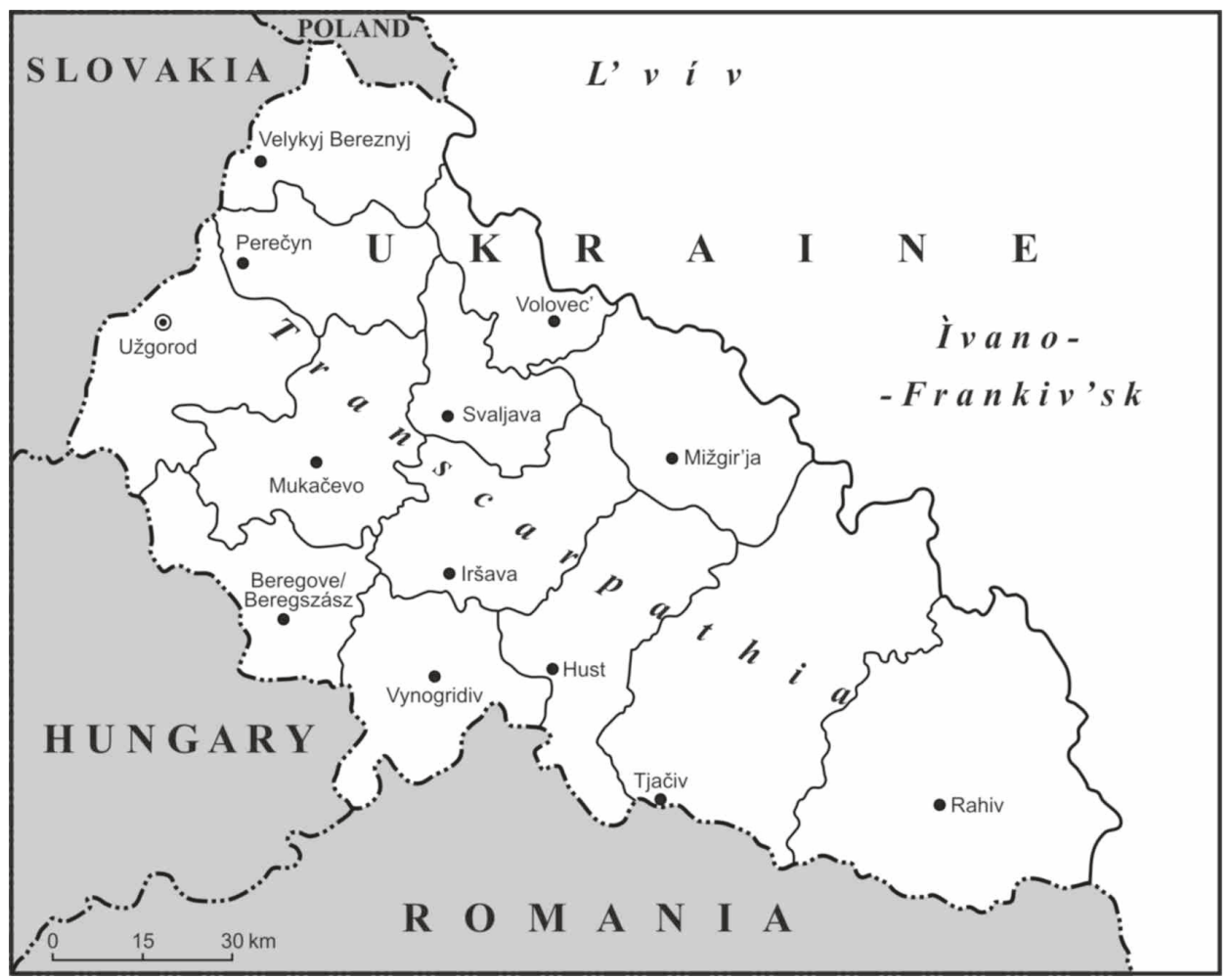

Ryc. 1. Podział administracyjny Rusi Zakarpackiej według rejonów w 2004 r.

Źr ó d ło: P. Jordan, M. Klemenčič, 2004, Transcarpathia - Bridgehead or Periphery? Geopolitical and Economic Aspects and Perspectives of a Ukrainian Region, Peter Lang. Europäischer Verlag der Wissenschaften, Frankfurt am Main, s. 282.

na możliwość sprzyjania poglądom separatystycznym wobec orientacji proukraińskiej. Dla autorów polskich są to kwestie mało istotne i używając pojęcia „Ruś Karpacka” lub bardziej precyzyjnie „Ruś Zakarpacka”, są wierni tradycyjnej formie staropolskiej, którą rozpowszechnił polski etnograf Oskar Kolberg². Niewykluczone, że w przyszłości przyjmie się nazwa „Ukraina Zakarpacka”, która będzie pozbawiona reminiscencji historycznych, a zgodna ze statusem politycznym tej peryferyjnej prowincji ukraińskiej3.

Wielkość terytorialna "Zakarpacia” też ulegała zmianom. Dopasowywała się ona zazwyczaj do podziałów politycznych i administracyjnych. Współczesna Ruś Zakarpacka jest mniejsza od tej jaka była w okresie przynależności do Królestwa Węgierskiego. Wówczas

Oskar Kolberg w ramach swego wielotomowego dzieła poświęconego ziemiom dawnej Polski przygotował odrębny tom 54 pt. "Ruś Karpacka”. Pierwotnie Kolberg ten tom zatytułował "Hucuły”, miał stanowić drugą część „Pokucia". Dotyczył głównie cech etnograficznych ludności góralskiej mieszkającej po północnej stronie Karpat. Obszary po południowej stronie Karpat Kolberg nazywał Rusią Węgierską i kilkakrotnie je odwiedzał. Niemniej jego monografia nie dotyczyła Zakarpacia (O. Kolberg 1970, s. V).

3 Według zgodnej opinii autorów, mówiąc o „Rusi Karpackiej” lub „Ukrainie Karpackiej” uwzględniamy większy obszar geograficzny niż ten, który obecnie wchodzi w skład obwodu zakarpackiego. Zawierać on powinien również obszary po północnej stronie Karpat zamieszkane przez Łemków lub Hucułów. Można tu przytoczyć pogląd znanego działacza łemkowskiego Wanio Hunianki: „Ruś Karpacka w swej naturze składa się z dwóch krain - Rusi Podkarpackiej na wschód od rzeki Uż i Kraju Łemkowskiego na zachód od rzeki Uż i San. Jednakże zjednoczenie polityczne tych dwóch krain w jedną Ruś Karpacką jest niemożliwe bez zjednoczenia politycznego Kraju Łemkowskiego, tzn. zachodniej części Rusi Karpackiej" (H. Duć-Fajfer 2003, s. 75). 
do tzw. Zakarpacia włączano cztery Komitaty: Máramaros, Bereg, Ugocsa i Ung, czyli tereny położone w dolinie górnej Cisy. Nowe granice polityczne ustalone w 1919 r. podzieliły te jednostki administracyjne. Zachodnia część Komitatu Ung znalazła się w Słowacji. Cała południowa część dużego Komitatu Máramaros oraz niewielkie skrawki Komitatu Ugocsa włączono do Rumunii. Z kolei dołączono małą część węgierskiego Komitatu Szabolcs ${ }^{4}$. Po I wojnie światowej przez Ruś Zakarpacką rozumiemy to terytorium, które znalazło się w granicach międzywojennego państwa czechosłowackiego, a po 1945 r. zostało zaanektowane przez Związek Sowiecki (12,8 tys. km²).

\section{UWARUNKOWANIA POLITYCZNE I PRZEMIANY ETNICZNE} DO I WOJNY ŚWIATOWEJ5

Dzisiejsi mieszkańcy Rusi Zakarpackiej są mieszaniną wielu ludów, które podbijały to terytorium względnie kolonizowali je $\mathrm{w}$ przeciągu ostatnich kilku tysięcy lat. $\mathrm{W}$ dobie wędrówek ludów przechodziły przez ten obszar liczne grupy etniczne zmierzające do opanowania niziny panońskiej. Byli to Hunowie, Wandalowie czy Ostrogoci. Bardziej brzemienne w skutki było zasiedlenie od VII wieku tych ziem przez plemiona słowiańskie. Zaczęli oni w IX wieku tworzyć bardziej zorganizowane jednostki państwowe pozostające pod wpływem Rusi Kijowskiej oraz Wielkich Moraw. W tym też czasie na tereny Zakarpacia dotarli duchowni obrządku słowiańskiego związani ze świętym Cyrylem i Metodym. Dzięki ich wysiłkom Zakarpacie zostało schrystianizowane w obrządku greckim.

Decydującą rolę polityczną odegrało jednak opanowanie niziny panońskiej przez plemiona węgierskie. Dotarły one nad środkowy Dunaj poprzez Zakarpacie, a konkretnie wzdłuż doliny Cisy. Węgrzy zawładnęli w 903 r. Użhorodem, który następnie utrzymywali przez 1000 lat. Początkowo władza Węgrów miała charakter nominalny, ale od początku XIII wieku Zakarpacie stało się integralną częścią Królestwa Węgierskiego. Były to wówczas tereny bezludne, na które stopniowo od północy napływali wzdłuż dolin górskich osadnicy z Rusi Halickiej, od wschodu Wołosi, a od strony południowej Węgrzy, którzy kolonizowali obszary nizinne. Administracja królewska sprowadzała również Niemców, którzy zajmowali się górnictwem oraz uprawą winorośli. Poważne zniszczenia przyniósł najazd tatarski (1240/1241), ale ta peryferyjna prowincja została ponownie zagospodarowana. Powstało około 20 miast oraz kilkaset wsi.

Dalsze losy Zakarpacia były już związane z dziejami Węgier, które prowadziły wyniszczające wojny z Turcją. Po przegranej bitwie pod Mohaczem (1526) Zakarpacie zostało podzielone między Habsburgami, a książętami Siedmiogrodu. Wojny tureckie zdziesiąt-

\section{......}

4 Na mapie dołączonej do książki P. Jordana i M. Klemenčiča (2004, s. 278) określono wspomniane zmiany polityczno-administracyjne. W tej samej książce zamieszczono mapę współczesnego podziału administracyjnego obwodu zakarpackiego według rejonów (P. Jordan, M. Klemenčič 2004, s. 182). Autorzy wykorzystali nazewnictwo geograficzne w transkrypcji angielskiej, które jest najczęściej stosowane w atlasach wydawanych na Zachodzie. Mapa ta w formie oryginalnej zamieszczona jest w niniejszym tekście (ryc. 1).

5 Na łamach "Spraw Narodowościowych" ukazat się bardzo cenny artykuł o stosunkach narodowościowych na Rusi Zakarpackiej w przeddzień I wojny światowej i w okresie międzywojennym (M. Jarnecki 2005). Z tego powodu autor może pominać wiele istotnych kwestii, które zostały już opisane i zinterpretowane. Podobnie, nie zachodzi potrzeba odniesienia się do literatury przedmiotu, która została odnotowana i wykorzystana. Wspomniane opracowanie miało charakter historyczno-polityczny. Dlatego też ta szeroka problematyka naukowa będzie ujęta dość popularnie i powierzchownie. Uwaga będzie skoncentrowana na zagadnieniach geograficzno-demograficznych. Spojrzenie na kształtowanie się stosunków narodowościowych z różnej perspektywy badawczej daje możliwość zrozumienia tego, co się wydarzyło w ciągu ostatnich stu lat na Rusi Zakarpackiej. Zachodzity tam skomplikowane procesy polityczne, społeczne, demograficzne i świadomościowe. W dodatku ich dalsza ewolucja jest trudna do przewidzenia. 


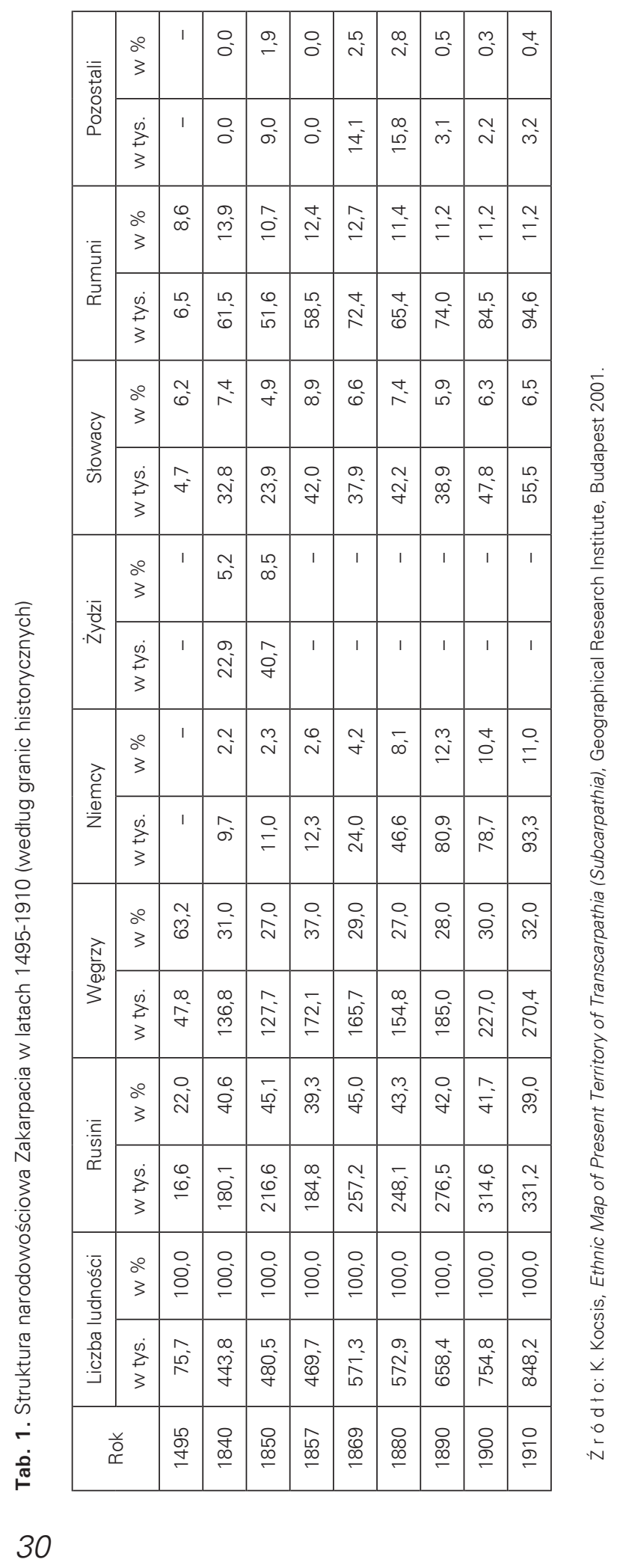


kowały ludność i zniszczyły miasta. Główne straty poniosła ludność węgierska zamieszkująca część południową Zakarpacia. W tym samym czasie na tereny górskie napływała stopniowo ludność słowiańska (ruska) z północy, która zdominowała językowo i religijnie większą część prowincji.

W okresie reformacji sytuacja była niezmiernie złożona na obszarze Węgier. Wiedeńscy Habsburgowie wspierali katolicyzm. Węgierscy książęta Siedmiogrodu - protestantyzm. Większość jednak mieszkańców pochodzenia słowiańskiego była wierna prawosławiu. Trwało to aż do unii kościelnych w Użhorodzie (1646) i w Munkaczu (1664), które to wzorując się na unii brzeskiej powołały Cerkiew greckokatolicką podporządkowaną Watykanowi, lecz zachowującą obrządek wschodni. Prawosławie zostało wyeliminowane z życia religijnego.

Po pokonaniu Turków nastąpiło wzmocnienie Austrii, która odłączyła Ruś Zakarpacką od Księstwa Siedmiogrodzkiego i włączyła do właściwych Węgier. Stabilna sytuacja polityczna ułatwiła rozwój prowincji, która stała się atrakcyjna dla migrantów zarówno Rusinów, Węgrów, ale również dla Niemców i Żydów. Wpłynęło to na pomyślny rozwój demograficzny. Według ocen dokonanych przez geografów węgierskich liczba ludności Zakarpacia (wg granic historycznych) wzrosła między 1495 a 1787 r. z 75,7 tys. do 234,4 tys. ${ }^{6} \mathrm{~W}$ późniejszym czasie tempo wzrostu było jeszcze wyższe. Działo się to pomimo, że od drugiej połowy XIX wieku miała miejsce duża emigracja do Ameryki. Proporcje między poszczególnymi grupami etnicznymi głównie zaś między Węgrami i Rusinami w ciągu XIX wieku były w miare stabilne. Rozmieszczenie ich też nie ulegało większym zmianom. Na górskich terenach położonych w Karpatach przeważali Rusini, zaś obszary nizinne położone na południu zamieszkiwali Wegrzy (tab. 1).

Przedstawione dane w tabeli wymagają krytycznego osądu, zwłaszcza dotyczące trzech przekrojów czasowych $(1495,1840,1850)$. Nie były to informacje uzyskane ze spisów powszechnych, lecz orientacyjne oszacowania. Zwłaszcza budzi wątpliwości wysoki udział procentowy Węgrów w 1495 r. W następnych latach liczebność ich była też wyraźnie zawyżona. W danych spisowych czyli od 1857 r. nie wyodrębniano ludności żydowskiej. Włączano ich automatycznie do ludności węgierskiej, rzadziej niemieckiej. Wyliczenia dokonano dla znacznie większego obszaru niż ten, który później znalazł się w państwie czechosłowackim, a później Ukraińskiej SRS. Terytorium to obejmowało dużą część komitatu Máramaros, w którym znajdowało się wielu Rumunów. Można założyć, że na przyjętym do analizy obszarze ludność węgierska stanowiła około $25 \%$ zaludnienia, zaś Rusini około $45 \%$. Obie te grupy etniczne skupiały więc około $70 \%$ ludności. Etniczne obszary węgierskie stanowiły razem $25 \%$ omawianego terytorium. Na pozostałym terytorium dominowała ludność rusińska o niezbyt wyrobionym poczuciu narodowym.

Badacz węgierski Kocsis określił potencjał demograficzny oraz skład narodowościowy dla współczesnego obszaru Rusi Zakarpackiej (Ukrainy Zakarpackiej) wg dwóch przekrojów czasowych (1880, 1910). Dzięki tej procedurze statystycznej dane są porównywalne do późniejszych czechosłowackich i sowieckich spisów ludności, gdyż podstawą jest to samo terytorium (tab. 2).

Dzięki pominięciu obszarów, które obecnie są w granicach Słowacji, Rumunii i w niewielkim stopniu Węgier obniżała się statystycznie liczebność Rumunów z 94,6 tys. do 11,4 tys. oraz Słowaków z 55,5 tys. do 6,3 tys. Proporcjonalnie wzrósł udział miejscowej ludności rusińskiej. Nadal jednak była zawyżona liczebność Węgrów i Niemców, gdyż Żydzi

6 Wyliczenia te zostały dokonane i zaprezentowane w pracach zawierających bogatą dokumentację statystyczną oraz interesującą ilustrację kartograficzną (K. Kocsis, E. Kocsis-Hodosi 1995, 1998; K. Kocsis 2001). 
Tab. 2. Struktura narodowościowa Rusi Zakarpackiej w latach 1880 i 1910

\begin{tabular}{|l|r|r|c|c|c|c|}
\hline \multirow{2}{*}{ Narodowość } & \multicolumn{2}{|c|}{1880} & \multicolumn{2}{c|}{1910} & \multicolumn{2}{c|}{ Zmiany 1880-1910 } \\
\cline { 2 - 7 } & w tys. & w $\%$ & w tys. & w \% & w tys. & w $\%$ \\
\hline Rusini & 244,7 & 59,8 & 331,6 & 55,4 & $+86,9$ & $+35,5$ \\
\hline Węgrzy & 105,4 & 25,7 & 184,3 & 30,8 & $+78,9$ & $+74,8$ \\
\hline Niemcy & 31,8 & 7,8 & 63,3 & 10,6 & $+31,5$ & $+99,0$ \\
\hline Stowacy & 8,6 & 2,1 & 6,3 & 1,1 & $-2,3$ & $-26,7$ \\
\hline Rumuni & 16,7 & 4,1 & 11,4 & 1,9 & $-5,3$ & $-31,7$ \\
\hline Pozostali & 1,8 & 0,5 & 2,0 & 0,2 & $+0,2$ & $+11,1$ \\
\hline Ogółem & 409,0 & 100,0 & 598,9 & 100,0 & $+189,9$ & $+46,4$ \\
\hline
\end{tabular}

Ż r ó d † o: K. Kocsis, Ethnic Map of Present Territory of Transcarpathia (Subcarpathia), Geographical Research Institute, Budapest 2001.

byli wówczas traktowani jako odrębna grupa religijna, a nie narodowościowa i zgodnie ze znajomością języka byli włączani do narodowości węgierskiej lub niemieckiej. W tym okresie władze Budapesztu prowadziły aktywną, a nawet bezwzględną politykę madziaryzacji. Starali się powiększyć w sposób rzeczywisty lub nawet pozorny liczebność ludności węgierskiej. Madziaryzacja polegała na wprowadzeniu języka węgierskiego nie tylko w administracji, szkolnictwie, ale nawet do Kościoła greckokatolickiego. Dla wielu aktywnych ludzi rodowodu rusińskiego wejście w orbitę języka i kultury węgierskiej było awansem społecznym i cywilizacyjnym. Pojawiła się grupa żyjąca na styku obu narodowości zwana Madziaronami. Byli oni lojalni wobec władzy węgierskiej, nastawieni niechętnie do obozu rusofilskiego i moskalofilskiego. Niektórzy z niech stawali się nawet nacjonalistami węgierskimi. Miało to jednak charakter sporadyczny. Ze względu na dużą różnicę lingwistyczną między dialektami autochtonicznej ludności rusińskiej, a językiem węgierskim akcja madziaryzacyjna nie przynosiła oczekiwanych rezultatów. W dodatku istniała wyraźna granica etniczna między terenami zamieszkanymi przez Węgrów i Rusinów, która cechowała się trwałością.

Sytuacja polityczna i narodowościowa, aż do I wojny światowej była stabilna. Miejscowi chłopi byli bierni i nie domagali się nie tylko autonomii, ale nawet nie żądali dla siebie większych swobód obywatelskich. Była to prawie w 100\% ludność wiejska, gdyż w miastach grupowali się Żydzi, Niemcy i Węgrzy. Ośrodki miejskie z wyjątkiem Użhorodu były małe. Pełniły jedynie funkcje usługowe dla biednego zaplecza rolniczego oraz nielicznej szlachty węgierskiej. Nie znaczy to, że nie pojawiły się pewne oznaki świadomości etnicznej. Pojawiła się nieliczna miejscowa inteligencja. Głównie byli to, podobnie jak we wschodniej Galicji, synowie duchownych greckokatolickich. Znając swój rodowód rusiński starali się być orędownikami ludu, z którego pochodzili. Wśród tych młodych i zaangażowanych ludzi ujawniły się trzy opcje polityczne. Pierwsza z nich była proukraińska i szukała zbliżenia z Ukraińcami mieszkającymi po drugiej stronie Karpat. Druga prorosyjska (moskalofilska) wskazywała, że naród karpatorusiński stanowi odłam wielkiego narodu rosyjskiego. Trzecia zaś tzw. rusińska (tutejsza). Ta ostatnia była długo popierana przez Węgrów. Uważali oni, że tworzenie się nacji karpatorusińskiej nie grozi wzrostem tendencji odśrodkowych. Ma ona charakter czysto regionalny i nie jest związana z ośrodkami zagranicznymi. Opcja

\footnotetext{
7 Problematyka ta doczekała się bogatej literatury przedmiotu. Zestaw współczesnych pozycji zawiera praca rosyjskiego badacza (I.I. Pop 2003).
} 
rusińska (rzadziej zwana rusnacką) też podlegała ewolucji ideowej8. Głównie wynikało to z obawy przed madziaryzacją. Oddziaływały na nią również rusińskie środowiska emigracyjne działające w Ameryce, które głosiły hasła separatystyczne i antywęgierskie. Wszystko to jednak działo się w społeczności mało licznej, biernej i o niskim poziomie wykształcenia.

Wśród ludności rusińskiej istniały odrębne grupy etnograficzne. Najbardziej z nich są znani Łemkowie ${ }^{9}$ zamieszkujący zbocza karpackie od Popradu na zachodzie po rzekę Osława na wschodzie, następnie Bojkowie od Osławy (od tzw. Wielkiego Działu), po rzekę Łomnicę oraz Huculi, których stolicą była Kołomyja. Ci ostatni graniczyli już z góralami rumuńskimi ${ }^{10}$. Różnili się oni między sobą obyczajami ludowymi oraz dialektami, jakich używali w życiu codziennym¹1.

Grupa nielicznych miejscowych liderów żyjących w drugiej połowie XIX w. reprezentowała bardzo różne poglądy na temat rozwiązania kwestii rusińskiej. Niemniej starała się działać na rzecz rozwoju oświaty i kultury. Pojawiały się różne czasopisma rusińskie wspierane przez miejscowych duchownych, w tym głównie biskupów. Została opublikowana w latach 40. XIX w. książka Michała Łuczkaja pt. „Historia Rusinów Karpackich” oraz pierwszy rusiński elementarz autorstwa Aleksandra Duchnowicza ${ }^{12}$. Celem tych działań oświatowych była obrona przed madziaryzacją oraz potencjalną ukrainizacją, która też mogła zagrozić tradycjom i wartościom regionalnym.

\section{SYTUACJA POLITYCZNA W OKRESIE I WOJNY ŚWIATOWEJ}

W trakcie I wojny światowej tysiące Rusinów zostało zmobilizowanych i wysłanych na front. Byli tam poddani różnym wpływom politycznym i ideologicznym. Wracając później do domu, bardziej byli świadomi swojej sytuacji oraz nabierali aktywności politycznej. Zwłaszcza, że to miało miejsce w czasie klęski militarnej i rozpadu Austro-Węgier. Wegry zostały ogarnięte rewolucją i stracity kuratelę nad peryferyjnymi prowincjami. Rząd komunistyczny Béla Kuna w Budapeszcie przyznał autonomię terytorialną czterem karpackim komitatom. Nie miało to dużego znaczenia, gdyż na terytorium Rusi Zakarpackiej wkroczyły okupacyjne wojska rumuńskie i czechosłowackie. Równocześnie na Zakarpaciu zaczęły się kształtować rusińskie rady narodowe. W miejscowości Jasiniach działacze proukraińscy utworzyli Republikę Huculską. Kolejne rady nawołujące do zjednoczenia się z Zachodnią Ukraińską Republiką Ludową powstały w miejscowościach: Chust, Swaława i Sygiet Mármaroski. Rada narodowa w Użhorodzie zadecydowała o powołaniu autonomicznego Za-

\section{$\cdots \cdots \cdot$}

8 Nazwa „Rusnak" nie dotyczyła nigdy ludności rusińskiej na ściśle określonym terytorium. Była ona zmienna w czasie. W pewnych okresach miała wymiar bardziej powszechny, w innych bardziej zanikała. Obecnie jest najbardziej popularna w północno-wschodniej Słowacji. Rusnacy to ludność greckokatolicka lub prawosławna żyjąca na południowych zboczach słowackich Karpat, używająca dialektów rusińskich z dużą domieszką słów słowackich. W ciągu ostatnich kilkudziesięciu lat ulega ona kulturowej i świadomościowej słowakizacji.

9 Do Łemków zalicza się głównie grekokatolików, rzadziej prawosławnych, żyjących do 1947 r. na północnych stokach Karpat w granicach współczesnej Polski. Zostali oni wysiedleni do Ukraińskiej SRS oraz na obszary zachodniej i północnej Polski. Na te tereny napłynęła ludność polska. Nieliczni z nich wrócili do swoich dawnych stron rodzinnych. Potomkowie tej ludności deklarują obecnie narodowość ukraińską, polską lub temkowską.

10 Bojkowie i Huculi mieszkający obecnie w tzw. części galicyjskiej Ukrainy deklarują narodowość ukraińską. Jeszcze w okresie międzywojennym przyznawali się oni częściej do narodowości rusińskiej.

11 Interesującą grupą etnograficzną są tzw. Boczwańcy. Są to potomkowie Rusinów, którzy wyemigrowali w XVIII wieku i osiedlili się w Wojwodinie. Zachowują do dzisiaj język rusiński oraz są świadomi swego pochodzenia karpackiego.

12 Informacje o działalności twórczej A. Duchnowicza zawarte są we wspomnianym artykule H. Duć-Fajfer (2003). 
karpacia w granicach Węgier. Zajęcie prowincji przez wojska czechosłowackie i rumuńskie udaremnito oddolne aspiracje narodowe miejscowych Rusinów. W dodatku klęska Ukraińców w wojnie z Polską po drugiej stronie Karpat zdezaktualizowała koncepcję proukraińską. Coraz bardziej realna i optymalna stawała się opcja proczechosłowacka, zwłaszcza że Czesi obiecywali autonomię i swobody obywatelsko-narodowe.

Decyzje co do przyszłości Rusi Zakarpackiej zapadły na konferencji pokojowej w Wersalu. Problem Rusi Zakarpackiej aż do 1918 r. nie istniał w polityce międzynarodowej. Pierwszy apel w tej sprawie został wystosowany dnia 12 listopada 1918 r. na Zjeździe Amerykańskiej Rady Narodowej Rusinów Węgierskich. Przyjęto wówczas rezolucję domagającą przyłączenia północno-wschodnich komitatów węgierskich do powstającej demokratycznej Czechosłowacji. Została ona następnie przekazana Tomaszowi Masarykowi, który powiadomił o tym fakcie prezydenta USA Woodrowa Wilsona, który ustosunkował się do niej przychylnie.

Kwestia przynależności politycznej Rusi Zakarpackiej była rozważana w trakcie Konferencji Wersalskiej. Stronę czechosłowacką reprezentował premier Karel Kramarz oraz minister spraw zagranicznych Edward Benesz. Wspierani oni byli przez przedstawicieli Karpatorusinów. Początkowo strona czeska nie domagała się włączenia Rusi Zakarpackiej do Czechosłowacji. Wskazywała jedynie na obiektywne uwarunkowania, które zmuszają do jednoznacznej decyzji, która nie jest łatwa. Dowodzili, że zjednoczenie węgierskich Karpatorusinów z galicyjskimi Ukraińcami jest niemożliwe ze względów fizjograficznych. Dzieli ich bowiem pasmo Karpat. Wspólne pochodzenie etniczne jest w takiej sytuacji kwestią drugorzędną. Z kolei większość ludności słowiańskiej Rusi Zakarpackiej domagała się definitywnego oderwania się od Węgier. Ponadto wskazywano na niebezpieczeństwo opanowania Rusi Zakarpackiej przez bolszewicką Rosję, w której planach jest wywołanie rewolucyjnego fermentu na Węgrzech i Austrii. Dopuszczenie ich za Karpaty byłoby niebezpiecznym precedensem o groźnych konsekwencjach politycznych. Argumentacja ta pośrednio wskazywała, że jedynym najbardziej optymalnym rozwiązaniem jest włączenie Rusi Zakarpackiej do Czechosłowacji. Daje to ponadto możliwość utworzenia wspólnej granicy między Rumunią a Czechosłowacją. Powstanie dzięki temu bariera przed zagrożeniem bolszewickim.

Przeciwnikiem tej koncepcji była delegacja ukraińska, która wykorzystywała argumentację etniczną. Dowodzono, że mieszkańcy Rusi Zakarpackiej są Ukraińcami, zaś terytorium to należało do Królestwa Halicko-Włodzimierskiego. To uzasadnienie nie zostało zaakceptowane, zwłaszcza, że delegacja czechosłowacka uzyskała wsparcie ze strony Centralnej Ruskiej Rady Ludowej. Obradowała ona w maju 1919 r. w Użhorodzie i poparła koncepcję związków unijnych z Czechosłowacją. Zaproponowano wówczas utworzenie federacji trójczłonowej o nazwie Republika Czesko-Słowacko-Ruska. W późniejszym czasie oczekiwano wyznaczenia granic tej nowej prowincji i jej kompetencji wobec rządu centralnego w Pradze i nadzorującej to postanowienie Ligi Narodów. Rada Najwyższa państw Ententy decyzją z dnia 16 czerwca 1919 r. postanowiła włączyć Ruś Zakarpacką do Czechosłowacji13. Kwestię formalnej przynależności uregulował traktat pokojowy z Saint-Germain-en-Laye (10 października 1919 r.). Zapewniał on między innymi szeroką autonomię, sejm krajowy i wybranego przez to ciało ustawodawcze gubernatora oraz mianowanie urzędników spośród miejscowych mieszkańców. Postanowienia te zostały usankcjonowane w nowej konstytucji czechosłowackiej. Problem południowej granicy Rusi Zakarpackiej został narzucony Węgrom, które były zmuszone dnia 4 czerwca 1920 r. podpisać w Trianon traktat pokojowy określający nowe granice państwa węgierskiego,

\footnotetext{
13 Przebieg obrad dotyczących przynależności politycznej Rusi Zakarpackiej na Konferencji w Wersalu oraz szczegółowe omówienie końcowych decyzji zawarte są książce: P.P. Żurawski vel Grajewski 1995, s. 46-55.
} 
w tym również granicę czechosłowacko-węgierską. W skład Rusi Zakarpackiej włączono szeroki pas o charakterze etnicznie węgierskim. Podobnie postąpiono na pograniczu węgiersko-słowackim. Liczna mniejszość węgierska znalazła się w granicach Rusi Zakarpackiej. Do dnia dzisiejszego przynosi to brzemienne reperkusje polityczne.

\section{PRZEMIANY NARODOWOŚCIOWE W OKRESIE MIĘDZYWOJENNYM}

Decyzje Paryskiej Konferencji Pokojowej w Wersalu w sprawie przynależności Rusi Zakarpackiej określity formalnie i faktycznie los mieszkańców tego historycznego regionu na dwadzieścia latt4. Rząd Republiki Czechosłowackiej dnia 17 grudnia 1919 r. powołał tzw. Dyrektorię, której przewodniczącym został Hryhorij Żatkowycz, która funkcjonowała do kwietnia 1920 r. W połowie tego roku Rumunia przekazała Czechosłowacji północny Máramaros, zachowując obszar na południe od Cisy zamieszkały w sposób zwarty przez ludność rumuńską.

Obiecana autonomia polityczna nie została przez władze centralne w Pradze wprowadzona w życie. Niemniej zapewniono swobody kulturowe, w tym wprowadzono szkolnictwo w języku rusińskim. Ochroniono kraj przed madziaryzacją, a nawet zapewniono ludności rusińskiej lepsze warunki niż Węgrom, którzy utracili pozycję dominującą w administracji i życiu polityczno-gospodarczym. Ich pozycja demograficzna też uległa osłabieniu. Wskazują to wyniki dwóch spisów ludności zrealizowanych w państwie czechosłowackim i ich porównanie do stanów poprzednich (tab. 3).

Tab. 3. Struktura narodowościowa Rusi Zakarpackiej w latach 1921 i 1930

\begin{tabular}{|l|c|c|c|c|c|c|}
\hline \multirow{2}{*}{ Narodowość } & \multicolumn{2}{|c|}{1921} & \multicolumn{2}{c|}{1930} & \multicolumn{2}{c|}{ Zmiany 1921-1930 } \\
\cline { 2 - 7 } & w tys. & w \% & w tys. & w \% & w tys. & w \% \\
\hline Rusini & 372,5 & 60,8 & 447,1 & 60,9 & $+74,6$ & $+20,0$ \\
\hline Węgrzy & 111,1 & 18,1 & 116,5 & 15,9 & $+5,4$ & $+4,9$ \\
\hline Niemcy & - & - & 13,3 & 1,8 & $+13,3$ & - \\
\hline Żydzi & 80,1 & 13,1 & 91,9 & 12,5 & $+11,8$ & $+14,7$ \\
\hline Słowacy & 19,3 & 3,1 & 34,0 & 4,6 & $+14,7$ & $+76,2$ \\
\hline Pozostali & 29,4 & 4,9 & 31,2 & 4,3 & $+1,8$ & $+6,1$ \\
\hline Ogółem & 612,4 & 100,0 & 734,0 & 100,0 & $+121,6$ & $+19,8$ \\
\hline
\end{tabular}

Ź r ó d † o: K. Kocsis, Ethnic Map of Present Territory of Transcarpathia (Subcarpathia), Geographical Research Institute, Budapest 2001.

W analizowanym okresie (1921-1930) udział ludności węgierskiej zmalał z 18,1 do 15,9\%. Jeszcze wyraźniejszy spadek był w stosunku do 1910 r. Nastąpiło więc stopniowe umocnienie żywiołu słowiańskiego. Po raz pierwszy uwzględniono w spisie ludność żydowską. Było jej ponad 90 tys. i skupiała się w nielicznych miastach, stanowiąc często połowę ich obywateli. Najważniejszą kwestią polityczną były jednak zmagania o opcję świadomościową miejscowych Rusinów. Stopniowej marginalizacji ulegała opcja moskalofilska, zaś wzmocnieniu opcja proukraińska. Dla emigracyjnych działaczy ukraińskich

\footnotetext{
14 Ruś Zakarpacka obok Kraju Kłajpedzkiego, Wolnego Miasta Gdańska oraz Wysp Alandzkich miała zagwarantowane przez system wersalski terytorialną autonomię narodowościową.
} 
oraz dla świadomych Ukraińców działających w Polsce Ruś Zakarpacka mogła stanowić swoisty Piemont mający ułatwić utworzenie w przyszłości niepodległej Ukrainy. Dlatego też ukrainizacja miejscowej ludności rusińskiej miała duże znaczenie polityczne. Pojawiła się liczna grupa świadomych Ukraińców, która rozpoczęła odpowiednią działalność propagandową. Pomimo, że nie przyniosła ona spektakularnych sukcesów, pojawiły się organizacje nawiązujące do ideologii Organizacji Ukraińskich Nacjonalistów (OUN). Równocześnie uaktywnity się partie bardziej separatystyczne, ukierunkowane na uzyskanie autonomii w ramach istniejącego układu politycznego. Zmierzały one do równouprawnienia miejscowej ludności rusińskiej. Sprzyjały tym planom uwarunkowania międzynarodowe.

\section{SYTUACJA POLITYCZNA PO DYKTACIE MONACHIJSKIM}

Przedstawiciele stronnictw rusińskich po układzie monachijskim i osłabieniu władzy centralnej w Pradze ogłosili 8 października 1938 r. autonomię Rusi Zakarpackiej w ramach istniejącej Republiki Czechosłowackiej. To żądanie zostało wstępnie zaakceptowane przez Pragę. Po krótkim premierostwie Andrieja Brodija premierem potencjalnej prowincji autonomicznej został 25 października 1938 r. ks. Augustyn Wołoszyn. Niedługo zarządzał całym krajem, gdyż na podstawie postanowień tzw. pierwszego arbitrażu wiedeńskiego wojska węgierskie zajęły między 5 listopada a 10 listopada 1938 r. południową część Rusi Zakarpackiej z Użhorodem i Munkaczem. Fakt ten osłabił ostatecznie orientację prowęgierską i umocnit siły proukraińskie i separatystyczno-niepodległościowe. Reprezentantem tych dwóch ostatnich był Wołoszyn. Przeniósł on swój „rząd” do miasteczka Chust i rozpoczął organizowanie formacji zbrojnych tzw. Siczy Karpackiej (9 listopada 1938 r.). Zgromadzenie Narodowe istniejącej jeszcze szczątkowej Czechosłowacji uchwaliło nową konstytucję przyznającą Rusi Zakarpackiej daleko idącą autonomię wewnętrzną. Nowa prowincja autonomiczna przyjęła nazwę Karpato-Ukrainy (Ukrainy Karpackiej).

Trwało to krótko, gdyż na skutek presji węgierskiej Hitler wyraził 11 marca 1939 r. zgodę na anektowanie przez Węgry całej Rusi Zakarpackiej. Prawie równocześnie, bo 14 marca 1938 r., sąsiednia Słowacja ogłosiła niepodległość. Stanowiło to ważny znak dla władz Rusi Zakarpackiej urzędujących w Chuście. Sejm Rusi Zakarpackiej na swym posiedzeniu w późnych godzinach wieczornych 14 marca 1939 r. ogłosit niepodległość oraz uchwalit konstytucję nowego suwerennego państwa o nazwie Karpato-Ukraina. Nie zostało ono uznane przez społeczność międzynarodową. Nie było na to zresztą czasu. W tym samym bowiem dniu (tj. 14 marca 1939 r.) na nieokupowane jeszcze terytorium Rusi Zakarpackiej (Karpato-Ukrainy) wkroczyła armia węgierska. Wojska czechosłowackie oraz oddziały Siczy Karpackiej dowodzone przez Mychajła Kołodzyńskiego stawiły dzielny opór, ale siły obu stron były nierówne. Walki trwały cztery dni do 18 marca 1939 r. Klęska militarna zakończyła istnienie tego efemerycznego państwa, ale odegrało to później pewne symboliczne znaczenie. Resztki pokonanych oddziałów Siczy Karpackiej przedarły się do Rumunii, gdzie zostały internowane, a ich dowódca został przez Węgrów ujęty i stracony. Wybrany 15 marca 1939 r. na prezydenta Karpato-Ukrainy ks. Augustyn Wołoszyn schronił się w Rumunii, skąd udał się do Pragi, w której przebywał do 1945 r. Tam został aresztowany przez NKWD i w lipcu 1945 r. zamordowany w Moskwie.

W tym krótkim dramatycznym okresie między 10 a 18 marca 1939 r. miało miejsce jeszcze jedno wydarzenie, a mianowicie 16 marca na przełęczy Tucholskiej w Karpatach 
nastąpiło uroczyste spotkanie wojsk polskich i węgierskich. Powstała wspólna granica polsko-węgierska, która była wówczas potraktowana jako doniosły fakt historyczny.

Parlament węgierski na specjalnej sesji w dniu 23 czerwca 1939 r. uznał uroczyście, że Ruś Zakarpacka stanowi integralną część Republiki Węgierskiej. Na podstawie tej uchwały 7 lipca 1939 r. wprowadzono na zajętych terenach administrację węgierską. Odtworzono stare, historyczne komitaty. Przywrócono więc stan jaki istniał w końcowej fazie I wojny światowej. Dla miejscowej ludności węgierskiej było to oczekiwane wyzwolenie, zaś dla Rusinów rozpoczął się pięcioletni okres okupacji15.

Władze węgierskie przeprowadziły w 1941 r. spis ludności, który wykazał 854,8 tys. mieszkańców, w tym Rusinów (Ukraińców) 502,3 tys. (58,9\%), Węgrów 233,8 tys. (27,3\%), Żydów 78,7 tys. (9,2\%), Rumunów 15,63 tys. (1,8\%), Niemców 13,3 tys. (1,5\%) oraz Słowaków 6,9 tys. (0,8\%). Na uwage zasługuje skokowy wzrost ludności węgierskiej. Wiązało się to z napływem ludności z Węgier, która z kolei po zakończonej wojnie powróciła do swoich poprzednich miejsc zamieszkania. W okresie okupacji węgierskiej rozpoczęła się eksterminacja ludności żydowskiej. Nie miała ona tak totalnego charakteru jak na terenach znajdujących się pod bezpośrednią kontrolą niemiecką. Dane powojenne (1946) ujawniły obecność jedynie 23,5 tys. Żydów, czyli 1/3 stanu przedwojennego.

Po wkroczeniu wojsk sowieckich zlikwidowano administrację węgierską, w tym kilkanaście tysięcy Węgrów zostało wywiezionych w głąb ZSRR. Następnie utworzono tzw. rady ludowe oraz zorganizowano zjazdy delegatów ludności nadzorowane przez NKWD. Ogłaszały one rezolucje domagające się włączenia Rusi Zakarpackiej do Ukraińskiej SRS. Równocześnie Stalin rozpoczął naciski na Rząd Republiki Czechosłowackiej przebywający na emigracji. Rząd Benesza, nawiązując do wcześniejszych porozumień, próbował bronić granic przedmonachijskich. Było to jednak bezskuteczne i w traktacie zawartym w Moskwie 29 czerwca 1945 r. Czechosłowacja definitywnie zrzekła się Rusi Zakarpackiej na rzecz ZSRR. Przy ostatecznej delimitacji granicy włączono do anektowanego terytorium część terenów należących do Słowacji, a mianowicie pas położony po zachodniej stronie rzeki Uż, między Użhorodem a Czopem.

\section{PRZEMIANY NARODOWOŚCIOWE W DRUGIEJ POLOWIE XX WIEKU}

Po opanowaniu przez armię sowiecką Rusi Zakarpackiej została ona włączona do Ukraińskiej SRS i uzyskała status obwodu. Od tego momentu została zlikwidowana nazwa Ruś, a przyłączona prowincja została nazwana oficjalnie obwodem zakarpackim Ukraińskiej SRS bądź w bardziej potocznym rozumieniu Ukrainą Zakarpacką. Nawet nie rozważano nadania jakiejkolwiek autonomii kulturowej. Wszyscy mieszkańcy uznający się dotychczas za Rusinów stali się automatycznie Ukraińcami, którzy podlegali ukrainizacji, względnie rusyfikacji oraz obejmującej wszystkich obywateli sowietyzacji. Istniejące mniejszości narodowe, a więc głównie Węgrzy, ale również Rumuni czy Słowacy uzyskali określone swobody językowe, w tym własne szkolnictwo. Musiały być jedynie lojalne wobec wszechobecnej doktryny komunistycznej. Zmiany narodowościowe o charakterze asymilacyjnym wynikały głównie z przemieszczeń migracyjnych, małżeństw mieszanych oraz procesów urbanizacyjnych.

Historia polityczna Zakarpacia w latach 1918-1945 została zaprezentowana w obszernej książce opublikowanej w Moskwie. Wykorzystano w niej głównie rosyjską literaturę przedmiotu oraz mało znaną dokumentację faktograficzną. Starano się w niej ukazać zamierzenia sąsiednich państw, które traktowały Ruś Zakarpacką jako obszar pozbawiony podmiotowości politycznej, etnicznej i ekonomicznej (A. Puškaš 2006). 
Przeobrażenia o charakterze etnicznym zachodziły stopniowo w sposób ewolucyjny. Polegały one przede wszystkim na zmniejszaniu się udziału ludności węgierskiej i umacnianiu się miejscowej ludności słowiańskiej. Miała ona większy potencjał demograficzny i była bardziej preferowana ze względu na swój rodowód i używany dialekt zbliżony do języka ukraińskiego i niezbyt odległy od języka rosyjskiego. Kolejne spisy ludności przeprowadzone przez władze sowieckie były w miarę wiarygodne i pokazywały liczebność i rozmieszczenie ludności według narodowości (tab. 4).

Tab. 4. Struktura narodowościowa obwodu zakarpackiego w latach 1959-1989

\begin{tabular}{|l|r|r|r|r|r|r|r|r|r|r|}
\hline \multirow{2}{*}{ Narodowość } & \multicolumn{2}{|c|}{1959} & \multicolumn{2}{|c|}{1970} & \multicolumn{2}{|c|}{1979} & \multicolumn{2}{c|}{1989} & \multicolumn{2}{c|}{$\begin{array}{c}\text { Zmiany } \\
1959-1989\end{array}$} \\
\cline { 2 - 12 } & w tys. & w $\%$ & w tys. & w \% & w tys. & w \% & w tys. & w \% & w tys. & w \% \\
\hline Ukraińcy & 685,5 & 74,6 & 808,1 & 76,5 & 896,6 & 77,8 & 976,8 & 78,4 & $+290,3$ & $+42,2$ \\
\hline Węgrzy & 146,2 & 15,9 & 152,0 & 14,4 & 158,5 & 13,7 & 155,7 & 12,5 & $+9,5$ & $+6,4$ \\
\hline Niemcy & 3,5 & 0,4 & 4,2 & 0,4 & 3,7 & 0,3 & 3,5 & 0,3 & 0,0 & 0,0 \\
\hline Żydzi & 12,2 & 1,3 & 10,9 & 1,0 & 3,8 & 0,3 & 2,6 & 0,2 & $-9,6$ & $-78,7$ \\
\hline Słowacy & 13,3 & 1,4 & 10,3 & 1,0 & 8,9 & 0,8 & 7,8 & 0,6 & $-5,5$ & $-41,3$ \\
\hline Rumuni & 18,4 & 2,0 & 23,5 & 2,2 & 27,2 & 2,3 & 29,5 & 2,4 & $+11,1$ & $+60,3$ \\
\hline Rosjanie & 29,6 & 3,2 & 35,2 & 3,3 & 41,7 & 3,6 & 49,5 & 4,0 & $+19,9$ & $+67,2$ \\
\hline Pozostali & 10,5 & 1,2 & 12,6 & 1,2 & 13,4 & 1,2 & 20,2 & 1,6 & $+9,7$ & $+92,3$ \\
\hline Ogółem & 920,2 & 100,0 & 1056,8 & 100,0 & 1155,8 & 100,0 & 1245,6 & 100,0 & $+325,4$ & $+35,4$ \\
\hline
\end{tabular}

Ź r ó d † o: Itogi Wsiezojuznoj pieriepisi nasielienija 1959, Moskva 1963 Itogi Wsiezojuznoj pieriepisi nasielienija 1970, Moskva 1972 Itogi Wsiezojuznoj pieriepisi nasielienija 1979, Moskva 1982. Nacjonalnyj sostaw nasielienija SSSR, Goskomstat SSSR, Moskva 1991

Podobnie jak w poprzednich okresach, prowincja już oficjalnie nazywana Ukrainą Zakarpacką, a według nomenklatury administracyjnej obwodem zakarpackim, odznaczała się wysoką dynamiką demograficzną. W ciągu trzydziestu lat (1959-1989) liczba ludności wzrosła o 325,4 tys. nowych obywateli. Wzrost ten dotyczył przede wszystkim Rusinów zwanych już Ukraińcami, którzy liczyli w 1989 r. blisko milion osób. Stopniowo zwiększała się liczebność napływowej ludności rosyjskiej. Obniżał się natomiast udział ludności węgierskiej, żydowskiej i niemieckiej. W tym okresie nastąpiła ukrainizacja miast, które dawniej skupiały Węgrów i Żydów. Proces ten był bardzo ważny, gdyż do II wojny światowej karpaccy Rusini byli głównie chłopską ludnością zajmującą się rolnictwem i pasterstwem. Ze względu na wagę zjawiska, które miało wymowę nie tylko etniczną, ale i społecznoekonomiczną warto zaprezentować dane w okresie ponad stuletnim dla dwóch największych miast opisywanej prowincji (tab. 5).

Analizując zaprezentowane zestawienie tabelaryczne odniesione do Użhorodu, należy zwrócić uwagę na istniejące zniekształcenie statystyczne. Ludność żydowska do I wojny światowej była zaliczana do narodowości węgierskiej oraz sporadycznie do niemieckiej. Natomiast w spisach czechosłowackich byli już uwzględniani jako odrębna grupa narodowościowa. Przyniosło to pozorne zmniejszenie się ludności węgierskiej między 1910 a 1921 r. z 73,5 do 32,0\% ogółu ludności Użhorodu, zaś tzw. grupa „pozostała”, do której zaliczono Żydów wzrosła z 9,0\% (1910) do 51,2\% (1930). Tego typu deformacje statystyczne dotyczą wszystkich miast usytuowanych na Rusi Zakarpackiej. Uwzględniając te 
zakłamania można stwierdzić, że do I wojny światowej w Użhorodzie przeważała ludność żydowska, ulegająca szybkiej językowej madziaryzacji, oraz węgierska. W okresie międzywojennym nadal dominowała ludność żydowska, lecz Węgrzy utracili swoją pozycję w administracji i w życiu społeczno-gospodarczym. Na krótko ją odzyskali po marcu 1939 r., aby po przegranej wojnie stać się dyskryminowaną mniejszością. Napływ ludności wiejskiej był przyczyną szybkiego wzrostu liczby ludności miasta, w którym około 2/3 stanowi aktualnie ludność ukraińska. Na miejsce coraz mniej licznych Żydów pojawiła się nieznana dotąd mniejszość, a mianowicie Rosjanie. W podobnym tempie następowała demadziaryzacja i dejudeizacja Munkaczu (Mukaczewa) ${ }^{16}$ (tab. 6).

Tab. 5. Struktura narodowościowa Użhorodu w okresie 1880-1989

\begin{tabular}{|c|c|c|c|c|c|c|c|c|c|c|}
\hline \multirow{4}{*}{ Rok } & \multicolumn{10}{|c|}{ Liczba ludności } \\
\hline & \multirow{2}{*}{\multicolumn{2}{|c|}{ ogółem }} & \multicolumn{8}{|c|}{ w tym } \\
\hline & & & \multicolumn{2}{|c|}{ Rusini, Ukraińcy } & \multicolumn{2}{|c|}{ Węgrzy } & \multicolumn{2}{|c|}{ Niemcy } & \multicolumn{2}{|c|}{ Pozostali } \\
\hline & w tys. & w \% & w tys. & w \% & w tys. & w \% & w tys. & w \% & w tys. & w \% \\
\hline 1880 & 14,8 & 100,0 & 2,4 & 16,4 & 9,2 & 62,2 & 0,9 & 6,3 & 2,3 & 15,1 \\
\hline 1900 & 18,9 & 100,0 & 2,9 & 15,5 & 12,6 & 66,5 & 1,4 & 7,2 & 2,0 & 10,8 \\
\hline 1910 & 21,6 & 100,0 & 2,4 & 11,1 & 15,9 & 73,5 & 1,4 & 6,6 & 1,9 & 9,0 \\
\hline 1921 & 25,7 & 100,0 & 5,7 & 22,3 & 8,2 & 32,0 & 0,5 & 1,8 & 11,3 & 43,9 \\
\hline 1930 & 35,6 & 100,0 & 10,6 & 29,9 & 5,8 & 16,4 & 0,9 & 2,5 & 18,3 & 51,2 \\
\hline 1941 & 38,7 & 100,0 & 6,8 & 17,5 & 28,0 & 72,4 & 0,3 & 0,7 & 3,6 & 9,4 \\
\hline 1979 & 89,0 & 100,0 & 57,9 & 65,0 & 7,6 & 8,6 & 0,1 & 0,1 & 23,4 & 26,3 \\
\hline 1989 & 116,1 & 100,0 & 81,1 & 66,8 & 9,2 & 7,9 & 0,1 & 0,1 & 25,7 & 25,2 \\
\hline
\end{tabular}

Ź r ó d † o: K. Kocsis, E. Kocsis-Hodosi, Ethnic Geography of the Hungarian Minorities in the Carpathian Basin Geographical Research Institute, Budapest 1998, s. 88.

Tab. 6. Struktura narodowościowa Munkaczu (Mukaczewa) w okresie 1880-1989

\begin{tabular}{|c|c|c|c|c|c|c|c|c|c|c|}
\hline \multirow{4}{*}{ Rok } & \multicolumn{10}{|c|}{ Liczba ludności } \\
\hline & \multirow{2}{*}{\multicolumn{2}{|c|}{ ogółem }} & \multicolumn{8}{|c|}{ w tym } \\
\hline & & & \multicolumn{2}{|c|}{ Rusini, Ukraińcy } & \multicolumn{2}{|c|}{ Węgrzy } & \multicolumn{2}{|c|}{ Niemcy } & \multicolumn{2}{|c|}{ Pozostali } \\
\hline & w tys. & w \% & w tys. & $w \%$ & w tys. & w \% & w tys. & $w \%$ & w tys. & w \% \\
\hline 1880 & 13,3 & 100,0 & 3,4 & 25,4 & 6,2 & 46,4 & 3,3 & 25,0 & 0,4 & 3,2 \\
\hline 1900 & 19,5 & 100,0 & 4,0 & 20,3 & 9,6 & 48,8 & 5,8 & 30,0 & 0,2 & 0,8 \\
\hline 1910 & 23,4 & 100,0 & 4,0 & 17,0 & 13,9 & 59,3 & 5,4 & 23,0 & 0,1 & 0,7 \\
\hline 1921 & 26,9 & 100,0 & 8,2 & 30,4 & 5,6 & 20,7 & 1,7 & 6,3 & 11,4 & 42,6 \\
\hline 1930 & 34,3 & 100,0 & 10,5 & 30,8 & 6,2 & 18,2 & 2,9 & 8,4 & 14,7 & 42,6 \\
\hline 1941 & 39,7 & 100,0 & 8,1 & 20,6 & 22,2 & 56,0 & 2,1 & 5,4 & 7,2 & 18,1 \\
\hline 1979 & 71,4 & 100,0 & 47,4 & 66,4 & 6,9 & 9,6 & . & . & 17,1 & 24,0 \\
\hline 1989 & 83,3 & 100,0 & 58,5 & 70,2 & 6,7 & 8,1 & 0,8 & 1,0 & 17,3 & 20,7 \\
\hline
\end{tabular}

Ź r ó d † o: K. Kocsis, E. Kocsis-Hodosi, Ethnic Geography of the Hungarian Minorities in the Carpathian Basin, Geographical Research Institute, Budapest 1998, s. 88.

16 Dawna tradycyjna polska nazwa to Munkacz. Po ll wojnie światowej coraz częściej używa się ukrainizowanej nazwy Mukaczewo. 
Procesy narodowościowe w Munkaczu zachodziły w analogiczny sposób jak w Użhorodzie. Do I wojny światowej najliczniejszą grupą etniczną byli niewyodrębnieni Żydzi, a następnie Węgrzy. Po II wojnie światowej nastąpiła slawinizacja miasta. Miało to miejsce również we wszystkich ośrodkach miejskich położonych na Zakarpaciu. Jedynie w nielicznych w 1989 r. dominowali Węgrzy, np. w Výlok (węg. Tiszaújlak) - 77,4\% oraz w Berehu Saskim (ukr. Beregove, węg. Beregszász) $-51,8 \%{ }^{17}$.

Odzyskanie przez Ukrainę niepodległości po rozpadzie ZSRR niewiele wniosło nowych zjawisk w stosunki narodowościowe. Miejscowa ludność podchodziła w sposób dość indyferentny do faktu, że Kijów stał się stolicą suwerennego państwa i nastąpił zmierzch sowietyzacji i rusyfikacji, która została zastąpiona ukrainizacją. Były to w dużym stopniu kwestie obojętne dla ludności żyjącej w izolacji w orbicie własnych spraw lokalnych. Bardziej dotknął mieszkańców kryzys ekonomiczny i obniżenie poziomu życia. Wzrost bezrobocia zmusił młodych ludzi do szukania pracy w pobliskich Węgrzech, Słowacji czy w Czechach. Niestabilne warunki wpłynęły na obniżenie dynamiki demograficznej. Przeprowadzony na Ukrainie spis ludności w 2001 r. uwzględnił kwestie narodowościowe i umożliwia porównanie sytuacji narodowościowej w stosunku do schyłkowego okresu sowieckiego (1989) (tab. 7).

Tab. 7. Struktura narodowościowa obwodu zakarpackiego w latach 1989-2001

\begin{tabular}{|l|r|r|r|r|r|r|}
\hline \multirow{2}{*}{ Narodowość } & \multicolumn{2}{|c|}{1989} & \multicolumn{2}{|c|}{2001} & \multicolumn{2}{c|}{ Zmiany 1989-2001 } \\
\cline { 2 - 6 } & w tys. & w $\%$ & w tys. & w \% & w tys. & w \% \\
\hline Ukraińcy & 976,8 & 78,4 & 1010,1 & 80,5 & $+33,3$ & $+3,4$ \\
\hline Węgrzy & 155,7 & 12,5 & 151,5 & 12,0 & $-4,2$ & $-2,7$ \\
\hline Rumuni & 29,5 & 2,4 & 32,1 & 2,6 & $+2,6$ & $+8,8$ \\
\hline Rosjanie & 49,5 & 4,0 & 31,1 & 2,5 & $-18,4$ & $-37,4$ \\
\hline Stowacy & 7,8 & 0,6 & 5,6 & 0,4 & $-2,2$ & $-28,2$ \\
\hline Niemcy & 3,5 & 0,3 & 3,5 & 0,2 & 0,0 & 0,0 \\
\hline Pozostali & 22,8 & 1,8 & 20,7 & 1,8 & $-2,1$ & $-8,8$ \\
\hline Ogółem & 1245,6 & 100,0 & 1254,6 & 100,0 & $+9,0$ & $+0,7$ \\
\hline
\end{tabular}

Ź r ó d † o: Nacjonalnyj sostav nasielienija SSSR, Goskomstat SSSR, Moskva 1991. www.ukrstat.gov.ua/Perepis/PidsPer-r.htm

Miejscowa ludność ukraińska (rusińska) w nowej sytuacji uzyskała większe możliwości kultywowania swoich tradycji kulturowych i językowych. Nadal obniżało się znaczenie Węgrów. W wyniku emigracji nastąpiło znaczne zmniejszenie się liczby ludności żydowskiej. Niemcy i Słowacy są nie tylko nieliczni, ale żyją w dużym rozproszeniu, co wpływa na ich stopniową marginalizację. Obniżyła się znacznie liczebność Rosjan. Było to wynikiem w pewnym stopniu procesów migracyjnych, ale też rezultatem zmiany opcji narodowościowej. Wielu zrusyfikowanych Ukraińców w czasie sowieckim deklarowało narodowość rosyjską, po staniu się obywatelami suwerennego państwa ukraińskiego wygodniej było uznać się za Ukraińców. Dane określone dla całego obwodu dają obraz dość zgeneralizowany i nie pokazują zróżnicowań przestrzennych. Z tego względu podane będą informacje statystyczne wg dwóch ostatnich spisów $(1989,2001)$ w układzie 4 miast rejonowych i 13 rejonów (tab. 8).

17 Do II wojny światowej w ogólnym użyciu była polska nazwa Bereh Saski. Obecnie stosuje się nazwę Beregowo lub Berehowo lub w formie ukraińskiej Beregove. 


\begin{tabular}{|c|c|c|c|c|c|c|c|c|c|c|c|c|c|c|c|c|c|c|c|}
\hline & $\begin{array}{l}\circ \\
3\end{array}$ & $\left|\begin{array}{c|}0 \\
10\end{array}\right|$ & \begin{tabular}{|l|}
$m$ \\
$\omega^{\circ}$
\end{tabular} & $\stackrel{\sim}{\sim}$ & $\stackrel{0}{\sim}$ & $\begin{array}{l}N \\
0\end{array}$ & $\stackrel{0}{\sim}$ & $\begin{array}{l}N \\
0\end{array}$ & $\stackrel{ナ}{\stackrel{+}{+}}$ & $\stackrel{\circ}{\mu^{\prime}}$ & $\cong$ & $\begin{array}{l}0 \\
0 \\
0\end{array}$ & $\bar{\sigma}$ & $\hat{0}$ & t. & t. & $\stackrel{+}{\sim}$ & $\begin{array}{l}m \\
m\end{array}$ & $\frac{\mathrm{a}}{4}$ \\
\hline $\begin{array}{l}\text { No } \\
\text { Q }\end{array}$ & $\frac{\infty}{2}$ & \begin{tabular}{|l|}
1 \\
0 \\
0
\end{tabular} & $\stackrel{\sim}{\sim}$ & \begin{tabular}{|l}
1 \\
0 \\
0
\end{tabular} & i & \begin{tabular}{l}
0 \\
\multirow{\sigma}{*}{}
\end{tabular} & $\stackrel{0}{\sim}$ & $\tilde{N}$ & $\underset{v}{\sim}$ & $\begin{array}{l}\infty \\
0 \\
0\end{array}$ & $\stackrel{\Xi}{-}$ & $\overline{0}$ & $\overline{0}$ & $\begin{array}{l}0 \\
0\end{array}$ & 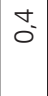 & $\tilde{O}$ & $\hat{\circ}$ & $\begin{array}{l}0 \\
i\end{array}$ & $\begin{array}{l}\infty \\
\stackrel{N}{N}\end{array}$ \\
\hline & $\begin{array}{l}\circ \\
3\end{array}$ & $\begin{array}{l}0 \\
\dot{\sigma}\end{array}$ & $\begin{array}{l}0 \\
0 \\
\end{array}$ & $\hat{\bar{m}}$ & t. & $\stackrel{i}{\text { i }}$ & $\hat{0}$ & $\begin{array}{l}0 \\
0 \\
0\end{array}$ & $\hat{0}$ & $\hat{\sigma}^{\circ}$ & $\cong$ & $\begin{array}{l}0 \\
0 \\
0\end{array}$ & $\stackrel{0}{=}$ & $\begin{array}{l}0 \\
0\end{array}$ & $\stackrel{0}{-}$ & L & $\stackrel{m}{-}$ & $\stackrel{\sim}{\stackrel{2}{-}}$ & $\stackrel{\sim}{\sim}$ \\
\hline 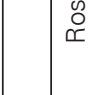 & $\sum_{3}^{\infty}$ & 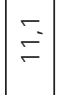 & $\stackrel{m}{\sim}$ & $\stackrel{\sim}{=}$ & $\stackrel{\sim}{\sim}$ & $\stackrel{\text { Pִ }}{-}$ & 告 & \begin{tabular}{|l|}
$\infty$ \\
0 \\
0
\end{tabular} & $\begin{array}{l}\Delta \\
0\end{array}$ & $\tilde{N}$ & $\stackrel{\forall}{-}$ & $\tilde{N}$ & $\stackrel{\infty}{-}$ & 0 & $\begin{array}{l}0 \\
0 \\
0\end{array}$ & $\tilde{O}$ & $\stackrel{+}{\circ}$ & o & $\overline{\bar{m}}$ \\
\hline & $\begin{array}{l}\circ \\
3\end{array}$ & 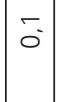 & $\overline{0}$ & $\bar{\sigma}^{\circ}$ & & & & & & & & & $\begin{array}{l}\stackrel{\Xi}{ \pm} \\
\simeq\end{array}$ & . & $\begin{array}{l}0 \\
- \\
-\end{array}$ & & & & $\stackrel{0}{i}$ \\
\hline  & 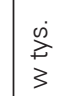 & $\overline{0}$ & $\overline{0}$ & $\overline{0}$ & & & & & & & & & $\stackrel{m}{\bar{\sim}}$ & . & \begin{tabular}{l}
\llcorner \\
$\circ$ \\
\hdashline \\
-
\end{tabular} & & & & $\overline{\tilde{N}}$ \\
\hline & $\begin{array}{l}\circ \\
3\end{array}$ & $\begin{array}{l}0 \\
0 \\
\infty \\
\infty\end{array}$ & \begin{tabular}{|l|}
10 \\
$\infty$ \\
$\infty$
\end{tabular} & $\begin{array}{l}\forall \\
\end{array}$ & $\underset{-}{-\infty}$ & $\stackrel{\vec{m}}{\stackrel{m}{m}}$ & $\stackrel{\widetilde{N}}{\stackrel{N}{*}}$ & $\begin{array}{l}\stackrel{a}{1} \\
\dot{m}^{\prime}\end{array}$ & $\begin{array}{c}\bar{c} \\
\overline{0}\end{array}$ & & $\begin{array}{l}\mathcal{N} \\
\underline{0} \\
\sim\end{array}$ & & $\stackrel{\Omega}{\sim}$ & $\overline{0}$ & $\stackrel{\sim}{m}$ & & 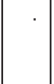 & $\hat{0}$ & 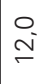 \\
\hline $3^{\infty}$ & 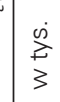 & $\begin{array}{l}0 \\
\infty^{\circ}\end{array}$ & $\stackrel{0}{\wedge}$ & 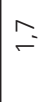 & 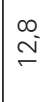 & \begin{tabular}{l}
$\infty$ \\
\multirow{\sim}{*}{}
\end{tabular} & $\stackrel{9}{\stackrel{9}{1}}$ & $\begin{array}{l}\infty \\
\tilde{m}^{-}\end{array}$ & $\begin{array}{l}\mathfrak{N} \\
\bar{\tau} \\
\end{array}$ & $\cdot$ & $\begin{array}{l}n \\
0 \\
0 \\
m\end{array}$ & & $\begin{array}{l}0 \\
0 \\
10\end{array}$ & $\bar{\sigma}$ & $\begin{array}{l}n \\
i\end{array}$ & & . & 吉 & مَ \\
\hline ) & $\begin{array}{l}0^{\circ} \\
3\end{array}$ & $\mid \begin{array}{l}\infty \\
\stackrel{1}{\nwarrow}\end{array}$ & $\approx$ & $\begin{array}{l}m \\
\infty \\
\infty\end{array}$ & $\begin{array}{l}0 \\
00 \\
\rho^{\circ}\end{array}$ & $\begin{array}{l}t \\
0 \\
\infty \\
\llcorner\end{array}$ & $\begin{array}{l}0 \\
\dot{0}\end{array}$ & $\begin{array}{c}0 \\
\stackrel{\circ}{\Omega} \\
\Omega\end{array} \mid$ & \begin{tabular}{|l|}
$\infty$ \\
$\infty$ \\
$\infty$ \\
-
\end{tabular} & $\begin{array}{l}m \\
8 \\
8\end{array}$ & $\frac{\dot{\pi}}{\dot{\pi}}$ & \begin{tabular}{|l|}
$\infty$ \\
$\infty$ \\
$\infty$ \\
$\infty$
\end{tabular} & $\begin{array}{c}0 \\
\tilde{N} \\
\infty\end{array}$ & $\mid \begin{array}{l}0 \\
\infty \\
0\end{array}$ & $\begin{array}{l}\infty \\
\infty \\
\infty\end{array}$ & $\bar{\Omega}$ & \begin{tabular}{|l|} 
\\
$\mathscr{c}^{\circ}$ \\
\end{tabular} & $\begin{array}{l}0 \\
\stackrel{\circ}{\sigma}\end{array}$ & $\begin{array}{l}0 \\
0 \\
0\end{array}$ \\
\hline$\frac{\bar{y}}{\partial}$ & $\underset{3}{2}$ & $\begin{array}{l}\infty \\
\mathscr{\Omega} \\
\infty\end{array}$ & $\begin{array}{l}0 \\
\text { ले } \\
0\end{array}$ & $\begin{array}{l}\forall \\
\stackrel{\sim}{\sim} \\
\stackrel{0}{*}\end{array}$ & m & $\stackrel{\llcorner}{\stackrel{\sim}{\sim}}$ & $\begin{array}{l}\mathcal{N} \\
\stackrel{1}{0} \\
\infty\end{array}$ & $\overline{\tilde{N}}$ & \begin{tabular}{l}
$N$ \\
\hdashline \\
\hdashline
\end{tabular} & $\stackrel{N}{\stackrel{N}{N}}$ & \begin{tabular}{|l|}
$m$ \\
$\infty$ \\
$\infty$ \\
\end{tabular} & $\begin{array}{l}\mathcal{N} \\
\stackrel{2}{N}\end{array}$ & 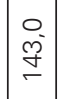 & $\begin{array}{l}m \\
\mathscr{g}\end{array}$ & $\begin{array}{l}\sim \\
\stackrel{0}{N}\end{array}$ & 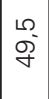 & $\begin{array}{l}0 \\
\dot{p} \\
\end{array}$ & $\stackrel{9}{\sigma}$ & б. \\
\hline \multirow{2}{*}{ 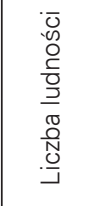 } & $\begin{array}{l}\alpha^{\circ} \\
3\end{array}$ & \begin{tabular}{l}
0 \\
\hdashline \\
\hdashline
\end{tabular} & \begin{tabular}{l}
$\circ$ \\
8 \\
\hdashline \\
\end{tabular} & $\stackrel{\circ}{\circ}$ & O & : & 品 & $\begin{array}{l}0 \\
\stackrel{0}{0}\end{array}$ & \begin{tabular}{l}
0 \\
$\stackrel{0}{0}$ \\
\hdashline
\end{tabular} & $\stackrel{0}{\circ}$ & $\begin{array}{l}0 \\
8 \\
8\end{array}$ & $\begin{array}{l}0 \\
8 \\
0\end{array}$ & \begin{tabular}{l}
0 \\
8 \\
\hdashline
\end{tabular} & $\begin{array}{l}0 \\
8 \\
8\end{array}$ & $\begin{array}{l}0 \\
\circ \\
0 \\
-\end{array}$ & $\begin{array}{l}0 \\
\circ \\
\circ\end{array}$ & \begin{tabular}{l}
0 \\
$\circ$ \\
\hdashline
\end{tabular} & $\begin{array}{l}0 \\
8 \\
\circ\end{array}$ & $\stackrel{\circ}{\circ}$ \\
\hline & $\underset{3}{\stackrel{i}{z}}$ & $\left|\begin{array}{c}6 \\
\stackrel{10}{\mp} \\
\leftarrow\end{array}\right|$ & $\begin{array}{l}0 \\
- \\
\infty \\
-\end{array}$ & $\frac{\Omega}{-}$ & $\begin{array}{l}0 \\
0 \\
\stackrel{0}{0}\end{array}$ & 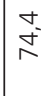 & 咅 & $\mid \begin{array}{l}\mathscr{\Omega} \\
\mathscr{\theta} \\
\mathscr{\sigma}\end{array}$ & $\begin{array}{l}0 \\
0 \\
10 \\
\end{array}$ & $\begin{array}{l}\stackrel{N}{o-j} \\
\stackrel{\sim}{\sim}\end{array}$ & $\begin{array}{l}0 \\
\infty^{\circ} \\
\leftarrow\end{array}$ & \begin{tabular}{|l|}
$\stackrel{\circ}{\rho}$ \\
$\stackrel{2}{N}$
\end{tabular} & $\begin{array}{c}0 \\
\stackrel{\Sigma}{\Sigma} \\
-\end{array}$ & $\begin{array}{l}0 \\
8 \\
8 \\
-\end{array}$ & $\begin{array}{l}8 \\
\dot{8}\end{array}$ & \begin{tabular}{|l|}
$\sigma$ \\
$\sigma$ \\
$g$
\end{tabular} & \begin{tabular}{|c|}
0 \\
$\hat{j}$ \\
$\tilde{m}$
\end{tabular} & \begin{tabular}{|l|l}
$\infty$ \\
$\infty$ \\
$\infty$ \\
0
\end{tabular} & $\begin{array}{l}0 \\
\stackrel{0}{\sim} \\
\stackrel{1}{\sim}\end{array}$ \\
\hline \multirow{3}{*}{  } & $\begin{array}{l}\frac{\widetilde{\sigma}}{\omega} \\
\frac{\omega}{\omega} \bar{\omega} \\
\frac{\omega}{2} \\
3\end{array}$ & 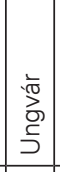 & 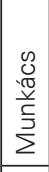 & \begin{tabular}{|l|}
$\mathbb{N}$ \\
D \\
I \\
\end{tabular} & 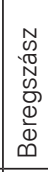 & 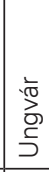 & 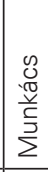 & $\mid \begin{array}{l}\mathbf{N} \\
\text { O } \\
\vec{I} \\
\end{array}$ & 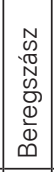 & 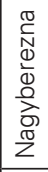 &  & $\begin{array}{l}0.0 \\
0 \\
\end{array}$ & $\begin{array}{l}: 0 \\
0 \\
0 \\
\mathbb{E} \\
\end{array}$ & \begin{tabular}{|l}
$\stackrel{0}{0}$ \\
0 \\
$\stackrel{0}{=}$
\end{tabular} & \begin{tabular}{|l|} 
\\
$\frac{0}{0}$ \\
$\simeq 0$ \\
$\simeq$ \\
\end{tabular} & 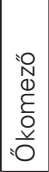 & 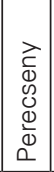 & 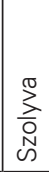 & \\
\hline & 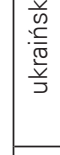 & 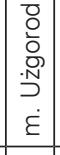 &  & 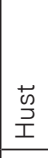 & \begin{tabular}{|l}
0 \\
0 \\
0 \\
0 \\
0 \\
0 \\
0 \\
0
\end{tabular} & 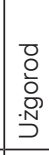 &  & $\begin{array}{l}+ \\
\stackrel{0}{0} \\
\underline{1}\end{array}$ & 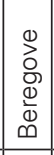 & 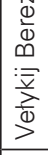 & \begin{tabular}{|l|}
$\geq$ \\
0 \\
0 \\
0 \\
0 \\
0 \\
$\mathbf{5}$ \\
$>$ \\
\end{tabular} & \begin{tabular}{|l|l}
0 \\
0 \\
0 \\
0 \\
\\
\end{tabular} &  & 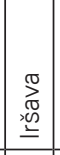 & 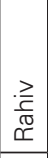 & 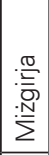 & 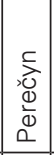 &  & \\
\hline & $\frac{\frac{\pi}{v}}{\frac{0}{0}}$ & 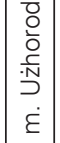 & 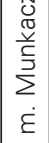 & 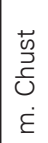 & 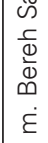 & 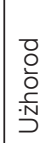 & 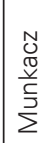 & 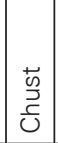 &  & 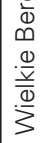 & 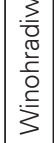 & $\begin{array}{l}0 \\
\frac{0}{3} \\
\frac{0}{0} \\
\frac{0}{0} \\
3\end{array}$ & 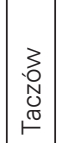 & 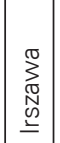 & \begin{tabular}{|l|}
3 \\
0 \\
$\frac{3}{0}$ \\
$\mathbb{0}$ \\
$\simeq \mathcal{1}$ \\
\end{tabular} & \begin{tabular}{|l}
0 \\
3 \\
0 \\
3 \\
3 \\
3
\end{tabular} & 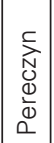 & $\mid$\begin{tabular}{|l}
$\frac{\pi}{3}$ \\
$\frac{\pi}{\pi}$ \\
$\frac{\pi}{\pi}$ \\
3 \\
0
\end{tabular} & \\
\hline
\end{tabular}


Analiza statystyczna według rejonów w sposób jeszcze bardziej wyrazisty ujawnia procesy demadziaryzacji. W czterech miastach rejonowych Węgrzy są już nieznaczną mniejszością. Jedynie w jednym rejonie (Bergove) ludność węgierska dominuje w dwóch pozostałych położonych na południu obwodu (Użhorod, Vinogradiv) obejmuje od 1/4 do 1/3 zaludnienia. W pozostałych rejonach stanowi już nieznaczny odsetek ludności. Do dokładniejszych studiów merytorycznych jednostki rejonowe też są za duże. Mają one zazwyczaj konfigurację południkową i obejmują w swoim składzie zarówno węgierskie jak ukraińskie (rusińskie) obszary etniczne. Pomimo, że węgierski obszar narodowy ulega stopniowemu kurczeniu się i zatraca swoją homogeniczność, to jednak wzdłuż granicy węgierskiej istnieją setki wsi, które mają charakter węgierski. Nadal istnieje równoleżnikowy pas o długości 120 km i szerokości od kilku do kilkunastu kilometrów, w którym ludność posługuje się w życiu domowym wyłącznie językiem węgierskim i nigdy nie straciła nadziei, że znowu znajdzie się w państwie węgierskim.

Węgierski obszar etniczny rozciąga się od granicy słowackiej na zachodzie po Taczów (Técső) na wschodzie. Do miejscowości o przewadze Węgrów należą: Czop (Csap), Mała i Wielka Dobron (Kisdobrony i Nagydobrony), Czomonin (Csongor), Batowo (Bátú), Barkasowo (Barkaszó), Rafajnowo (Ratajnaújfalu), Gut (Kélgút), Gat (Gät), Wielkie Beregi (Nagybereg), Wari (Vári), Wierbowiec (Verbőc), Szapanki (Salang), Wilok (Tiszaújak), Petrowo (Tiszapétefalva), Czepa (Csepe), Djula (Szőlgosgyula). We wschodniej części prowincji, na południe od rzeki Cisy, Węgrzy ulegają stopniowej marginalizacji.

$\mathrm{Na}$ terytorium obwodu zakarpackiego znajduje się niewielki rumuński obszar etniczny w pobliżu Dibrowy (węg. Alsóapsa, rum. Apsa de Jos), Sołotwina (węg. Aknaszlatina, rum. Slatina), Średnie Wodjanie (węg. Kőzepapsa, rum. Apsa de Mijloc) i Gtibokij Potik (węg. Szorospatak, rum. Volea Bocicolului).

\section{SEPARATYZM KARPATORUSIŃSKI NA ZAKARPACIU}

Dotychczasowa analiza dotyczyła głównie zagadnień historyczno-demograficznych. Przedstawiono dzieje niewielkiej prowincji geograficznej, która różnie była nazywana przez własnych mieszkańców oraz przez otaczających ją sąsiadów. Kraina ta, a w zasadzie region w ciągu swej tysiącletniej historii miała tyko kilkudniowy suwerenny byt państwowy (od 14 do 18 marca 1939 r.). Przed tym krótkim epizodem kraina ta należała blisko 1000 lat do Węgier. Większość mieszkańców tego peryferyjnego obszaru związanego z Królestwem Węgierskim odróżniała się od rdzennych Węgrów językiem (słowiański wobec ugrofińskiego). Ponadto dzieliła ich bariera religijna. Węgrzy byli związani z katolicyzmem lub protestantyzmem. Miejscowa ludność słowiańska początkowo była prawosławna a później greckokatolicka. Będąc wierna wielowiekowej spuściźnie bizantyjskiej, czuła swą odrębność kulturową w stosunku do łacińskiego Zachodu, którego przedstawicielami byli Węgrzy. Te istotne różnice etniczne uniemożliwiały wtopienie się tej chłopsko-pasterskiej ludności w naród węgierski. W dodatku mieszkający na nizinach Węgrzy preferowali inny model życia i folklor ludowy niż żyjąca na terenach górskich ludność rodowodu słowiańsko-wołoskiego.

W rezultacie dość zaskakujących okoliczności politycznych ta leżąca na styku kilku granic prowincja po I wojnie światowej została włączona do Czechosłowacji. W momencie rozpadu tego państwa po werdykcie monachijskim znalazła się w granicach Węgier. Trwało to zaledwie kilka lat i po wkroczeniu armii sowieckiej nastąpiła kolejna zmiana przynależności 
politycznej i oficjalne nadanie nowej nazwy. Powstał obwód zakarpacki, należący integralnie do niesuwerennego państwa, jakim była Ukraińska SRR. Po odzyskaniu przez nią niepodległości status polityczno-administracyjny prowincji jak i jej nazwa nie uległy już zmianie.

Terytorium zamieszkane przez ludność karpatorusińską zmieniało w ciągu XX w. kilkakrotnie swoją przynależność polityczną. Ludność ta podlegała asymilacji (np. w Słowacji) i przesiedleniom (np. w Polsce). Z tego też powodu zmieniał się obszar, w którym w sposób zwarty zamieszkiwała. Przeobrażenia te zostaną pokazane na dwóch mapach zamieszczonych w tekście (ryc. 2 i 3). Nastąpił zanik osadnictwa karpatorusińskiego (Łemków) na terytorium Polski, zmniejszył się obszar etniczny wspomnianej ludności na Słowacji. Jedynie w obwodzie zakarpackim pozycja ludności rusińskiej uległa wzmocnieniu, a nawet z niektórych przygranicznych obszarów zostali wyparci. Na tych dwóch mapach zgodnie z przyjętą konwencją nie uwzględniono Karpatorusinów (np. Hucułów) mieszkających w innych obwodach ukraińskich.

Rozpatrując sytuację demograficzną-etniczną Rusi Zakarpackiej, a następnie Ukrainy Zakarpackiej zwrócono uwagę nie tylko na rozwój ludnościowy, ale przede wszystkim na strukturę narodowościową. Była ona dość złożona w wymiarze geograficznym i strukturalnym. Przeważała greckokatolicka ludność słowiańska (rusińska), ale było wielu Węgrów, Rumunów i Słowaków. Zwłaszcza Ci pierwsi byli liczni, dobrze zorganizowani i zdecydowanie dominowali w południowej nizinnej części kraju. Do mniejszości narodowych należeli wyodrębniający się z otoczenia Niemcy i Żydzi. Ortodoksyjna ludność żydowska przeważała w miastach, żyjąc $w$ orbicie swojej religii i tradycyjnych obyczajów. Te kwestie zwłaszcza od strony statystycznej zostały wyjaśnione i nigdy nie budziły naukowych

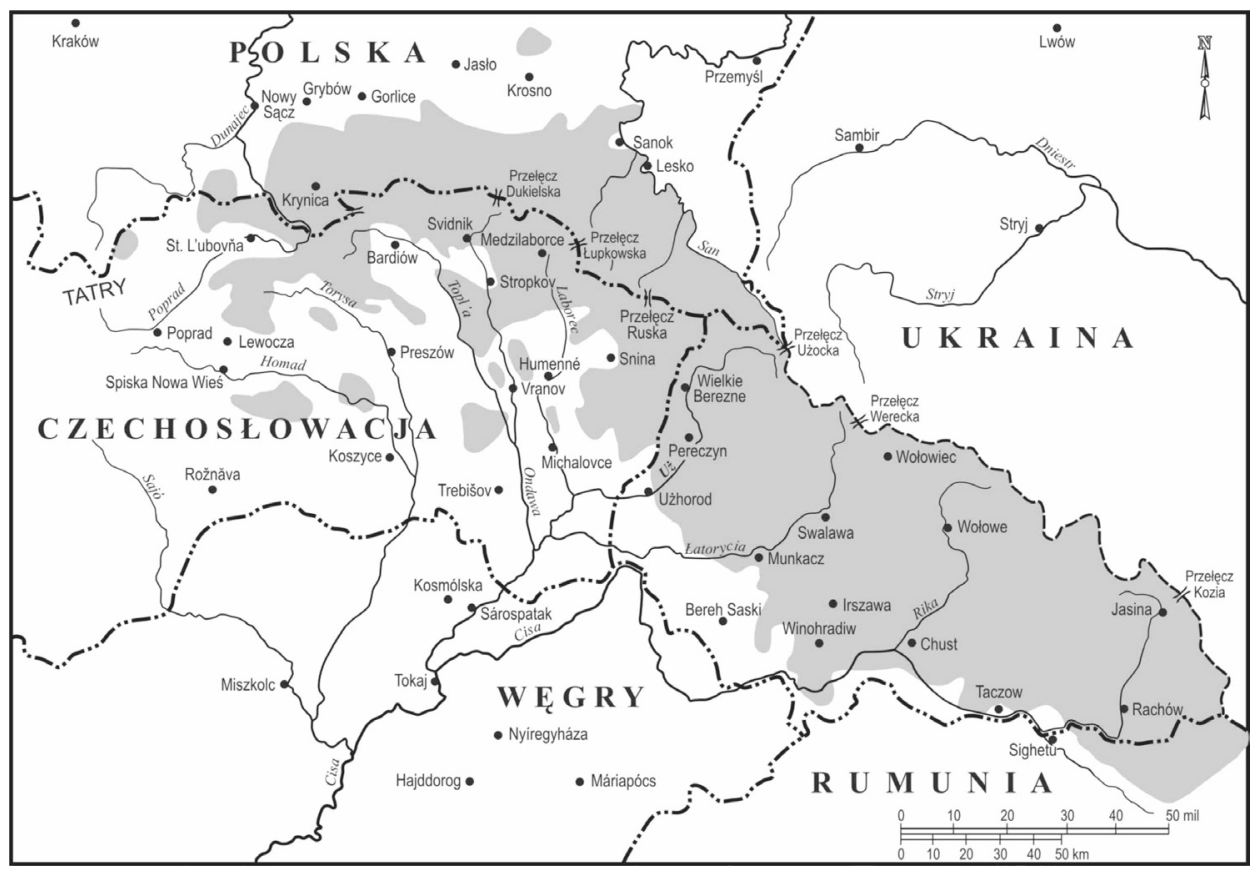

Ryc. 2. Obszar etniczny Karpatorusinów w 1910 r.

Źr ó d to: P.R. Magocsi, 1992, Karpato-Rusini: obecny status i perspektywy. Kto to są Rusini?, „Sprawy Międzynarodowe", nr 7-12, s. 96, Warszawa. 


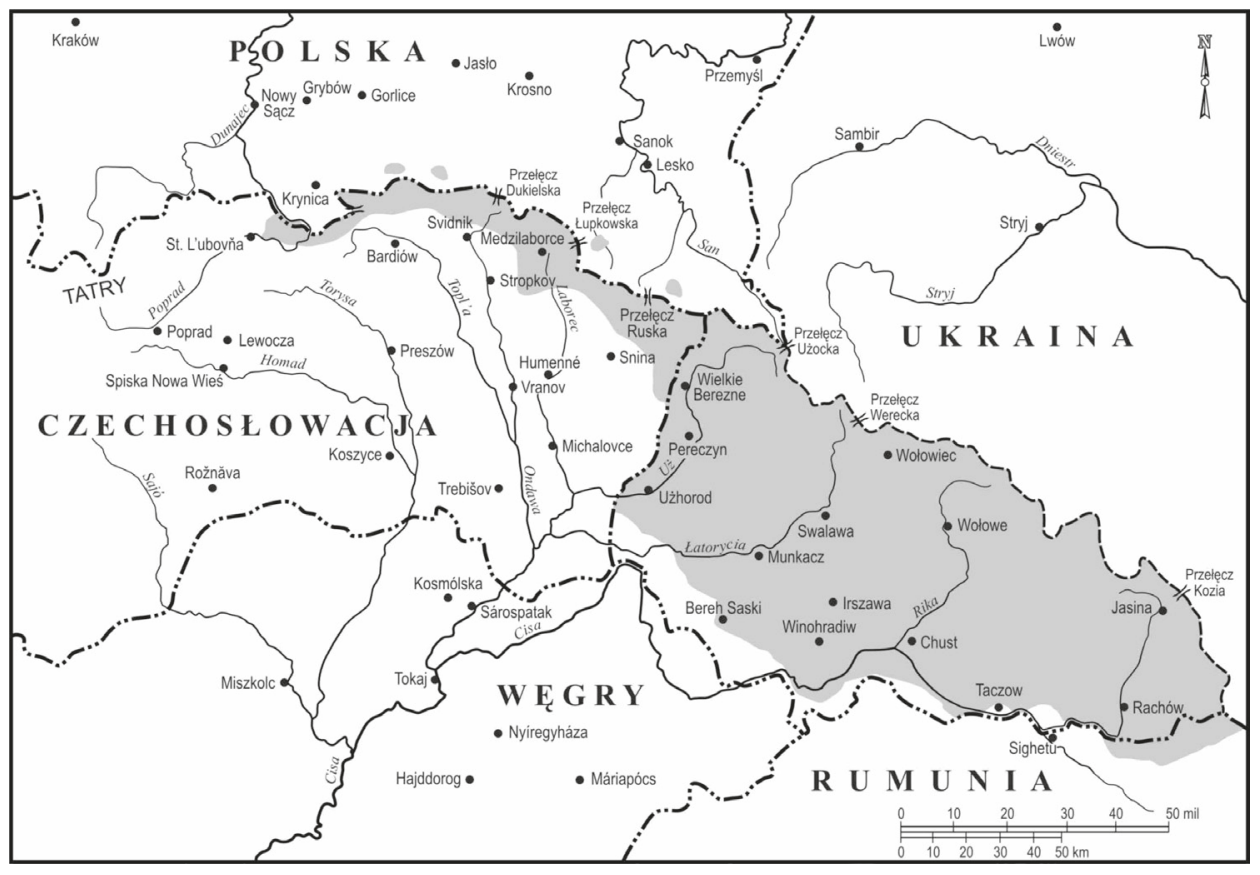

Ryc. 3. Współczesny obszar etniczny Karpatorusinów.

Źród to: opracowanie własne.

kontrowersji. Natomiast istnieje niezmiernie ważny problem, który do tej pory nie został rozstrzygnięty. Dotyczy tożsamości etnicznej, a w zasadzie przynależności narodowej autochtonicznej ludności rusińskiej (ukraińskiej). W tej złożonej dziedzinie jest wiele wykluczających się hipotez i poglądów, które mają wydźwięk nie tyle naukowy, co bardziej polityczny. Formułowane są opinie, że lud karpatorusiński jest całkowicie odrębnym narodem i zasługuje na własną podmiotowość polityczną ${ }^{18}$.

Diametralnie odmienny pogląd wyrażają badacze ukraińscy, którzy stoją na stanowisku, że ludność zamieszkała na tzw. Ukrainie Zakarpackiej jest integralną częścią narodu ukraińskiego i różni się od niego jedynie folklorem ludowym. Stanowi jedynie jedną z wielu grup etnograficznych, na które jest podzielony naród ukraiński19. Obok tych dwóch skrajnych podejść funkcjonują pośrednie, które mniej lub bardziej uwypuklają różnice, jakie wykształcity się u Rusinów żyjących w specyficznych warunkach politycznych i cywilizacyjno-kulturowych. Według tych opinii nie można w pełni identyfikować Karpatorusinów nie tylko z naddnieprzańskimi, ale nawet wołyńskimi czy galicyjskimi Ukraińcami. Wysuwane w tej debacie argumenty raz uwypuklają różnice, innym razem podobieństwa.

\section{......}

18 Tego rodzaju pogląd reprezentuje amerykański historyk, autor wielu książek o Rusinach, Paul Robert Magocsi. Jest on zwolennikiem istnienia narodu karpatorusińskiego. Uważa on, że na terenie obecnej Polski, Słowacji i Ukrainy mieszka około 1,2 mln ludności deklarującej narodowość karpatorusińską, do której zaliczył Łemków, Rusnaków, Hucułów i Bojków. Ludność ta nie poczuwa się do narodowości ukraińskiej i ma wyraźne poczucie swojej rusińskiej odrębności, nie tylko etnograficznej, ale i narodowej. Są czwartym narodem wschodnio-słowiańskim obok Rosjan, Ukraińców i Białorusinów. Koncepcję tę propaguje w licznych opracowaniach (np. P.R. Magocsi 1992, 1994, 2002).

19 Poglądy negujące odrębność narodową Rusinów karpackich prezentowała sowiecka literatura przedmiotu, jak i badacze niepodległej już Ukrainy (P. Sterčo 1994). 
Utworzenie się ukształtowanej świadomości narodowej wymaga długiego czasu. Bywają jednak wyjątkowe sytuacje, na przykład w warunkach konfliktów etnicznych, gdy proces ten może ulec przyspieszeniu i doprowadzić w krótkim stosunkowo okresie do wyodrębnienia się jednoznacznej identyfikacji narodowej. Bywa również, że zainicjowane idee narodowe obumierają i tendencje integracyjne $w$ ramach większych zbiorowości narodowych zaczynają przeważać nad procesami odśrodkowymi. Dążenia niepodległościowe były zawsze słabo artykułowane wśród mieszkańców obwodu zakarpackiego, natomiast idee separatystyczne były bardziej wyraziste. Niemniej i one rozwijały się cyklicznie i miały zwykle charakter koniunkturalny i powierzchowny. Działaczom, którzy go promowali brakowało wiary, konsekwencji i determinacji. Jednym z inicjatorów separatyzmu rusińskiego był Augustyn Sztefan. Na przełomie lat 20. i 30. XX w. był on twórcą partii "Oswobodzenie" i autorem manifestu, w którym odrzucił orientację ukraińską i rosyjską. Stworzył pojęcie „rusinizmu”. Poparł go biskup mukaczewski Aleksander Stojka, który wspierał język karpatorusiński. Usiłowania te nie przyniosły większego sukcesu, gdyż masy ludowe były bierne, a wśród nielicznej miejscowej inteligencji byli również zwolennicy kierunku moskalofilskiego i ukrainofilskiego ${ }^{20}$.

Społeczność Karpatorusinów ma wiele atrybutów, które potencjalnie rzecz biorąc mogą być podstawą uformowania się narodu. Ludność rusińska zamieszkuje ściśle określone terytorium. Ma swoiste cechy etniczne, które ich oddzielają od sąsiadów. Pomimo, że jest podzielona na kilka grup etnograficznych, ale jako całość czuje wyraźną odrębność wobec ludności ukraińskiej zamieszkującej obszary usytuowane po północnej stronie Karpat. Łączy te dwie społeczności wspólnota religijna, ale granica polityczna, która istniała przez 1000 lat izolowała je od siebie i doprowadziła do dużych różnic mentalnych. Pozostałe rozgraniczenia etniczne są już bardzo wyraziste. Dotyczy to granicy wschodniej, południowej i zachodniej (z Rumunami, Węgrami i Słowakami). Bardzo wyraźną cechą etniczności obok religii są kwestie językowe. Niektórzy lingwiści traktują język mieszkańców obwodu zakarpackiego jako gwarę języka ukraińskiego, inni zaś jako odrębny język odbiegający od tego jaki używają Ukraińcy. Ze względu na kontrowersje w tej dziedzinie warto przytoczyć jedną z opinii:

"Chociaż językoznawcy uznają tę mowę za dialekt języka ukraińskiego, posiada on zupełnie odrębną leksykę, stały akcent (zwykle na pierwszej sylabie), a długość wymawiania samogłosek nie zależy w niej tak jak w ukraińskim, rosyjskim i białoruskim od tego, czy pada na nią akcent. Ta cecha łączy mowę ze słowackim i czeskim. Poza tym mowa rusińska ma dość duży zasób słów bliższych językowi słowackiemu niż ukraińskiemu. Zapożyczenia rumuńskie dotyczą gospodarski pasterskiej. W następnej kolejności są zapożyczenia węgierskie, wiele jest niemieckich. Jednakże nade wszystko mowa ta posiada coś czego nie sposób ująć w językoznawczej definicji - jej duch i jej melodia świadczą o przynależności jej użytkowników do kręgu kulturowego odrębnego od wschodniosłowiańskiego" (P. Przeciszewski 2007, s. 112).

W dalszej części artykułu autor zwraca uwagę, że język karpatorusiński jest w powszechnym użyciu, nie tylko wśród ludzi prostych, ale również używa go miejscowa inteligencja.

Mówiąc o kwestiach językowych nie można pomijać faktu, że nie zawsze odrębność językowa umożliwia powstanie narodu21. Aby grupa etniczna stała się narodem musi ona do tego celu zmierzać w sposób świadomy. Zrealizowanie programu niepodległościowego wymaga konsekwencji, determinacji, a często ofiar. Ocena w jakiej fazie jest proces narodowościowy wśród Rusinów Karpackich jest bardzo trudna. Musi siłą rzeczy

- • • •

20 Tematyka ta nie wymaga prezentacji, gdyż została dokładnie zrelacjonowana w artykule J.J. Bruskiego (1995).

21 Problem relacji między językiem, narodem i państwem omawia interesująca książka R. Szula (2009). 
mieć charakter dość subiektywny, gdyż wszelkie wnioski w tej dziedzinie można jedynie konstruować na podstawie wartości symbolicznych i emocjonalnych związanych bardziej z imponderabiliami niż faktami wymiernymi ${ }^{22}$. Te zaś przybierają postać wydarzeń incydentalnych, których oddźwięk polityczny nie jest zbyt doniosły. Są bowiem autorstwa nielicznej grupy osób, które są traktowane przez ogół społeczeństwa rusińskiego z dużą rezerwą, a nawet obojętnością. Można przytoczyć kilka wydarzeń, które pomimo rozgłosu propagandowego nie przyniosły wyraźniejszych konsekwencji politycznych.

Między innymi z inicjatywy Towarzystwa Odrodzenia Rusinów zwołano w marcu 1991 r. w Medzilaborcach w Słowacji I Światowy Kongres Rusinów²3. Zebrali się tam przedstawiciele społeczności rusińskiej z Ukrainy, Polski, Czechosłowacji, Jugosławii oraz reprezentanci z diaspory amerykańskiej. Stwierdzono na tym Kongresie, że Rusini stanowią odrębny naród posiadający swój język. Z tego powodu domagają się uznania tego faktu i przyznania autonomii terytorialnej na tych obszarach, na których przeważają. Równocześnie jednak potwierdzono status quo istniejących granic politycznych.

Ruch rusiński w wielu swoich dokumentach domaga się od Ukrainy uznania, że w obwodzie zakarpackim żyją obywatele określający się jako Rusini, odrębni narodowościowo od Ukraińców. Powinni oni mieć prawo określania swej narodowości w dokumentach państwowych i należy ich traktować jako równouprawnionych obywateli suwerennego i demokratycznego państwa ukraińskiego. W przypadku zapewnienia im tych uprawnień nie wysuwają oni żadnych postulatów secesyjnych i niepodległościowych. Wystosowano równocześnie apel do rządu polskiego i słowackiego o oficjalne uznanie na swoim terytorium istnienia dwóch jasno sprecyzowanych orientacji narodowościowych: ukraińskiej i rusińskiej. Tego typu żądania są dość umiarkowane i nie mogą zagrozić integralności państwa ukraińskiego, polskiego i słowackiego.

W odpowiedzi na dezyderaty strony rusińskiej węgierska mniejszość zażądała, aby w ramach istniejącego porządku administracyjnego wprowadzić autonomię dla południowego pasa przygranicznego, w którym od stuleci dominuje. Można założyć, że w przypadku poważniejszych zawirowań politycznych będzie ona optowała za przyłączeniem do sąsiedniego państwa węgierskiego. Ta realna groźba działa pacyfikująco na działaczy rusińskich obawiających się dezintegracji terytorialnej obwodu zakarpackiego.

W następnych latach kwestie podmiotowości mieszkańców obwodu zakarpackiego były obiektem dyskusji bardziej naukowej niż politycznej. Wypowiadanie były opinie o konieczności zagwarantowania większej autonomii terytorialnej. Na ten postulat była ogólna zgoda tak władzy lokalnej jak i mieszkańców. Nie to jednak było obiektem większego zainteresowania społeczeństwa. Trudne warunki bytu wywołane transformacją ustrojową bardziej ciążyły mieszkańcom niż brak swobód narodowych. Sprawy te dopiero w końcu 2008 r. stały się bardziej głośne, a mianowicie w październiku 2008 r. odbył się w Munkaczu II Europejski Kongres Rusinów Karpackich. Została na nim ogłoszona restytucja Republiki Rusi Podkarpackiej w ramach Ukrainy ${ }^{24}$.

\section{-....}

22 O nastawieniu miejscowej ludności do przeszłości świadczy fakt, że w Użhorodzie został postawiony pomnik ks. A. Wołoszyna. Wołoszyn jest również patronem jednej z głównych ulic miasta. Te decyzje władz lokalnych zostały zaakceptowane przez władze centralne w Kijowie, które nie traktują Wołoszyna jako separatysty, gdyż był on twórcą państwa o nazwie Ukraina Karpacka.

23 Informacje o postulatach wystosowanych na Kongresie w Medzilaborcach zawiera artykut opublikowany w języku polskim (P.R. Magocsi 1992).

24 Liderzy miejscowych separatystów, ks. Dimitrij Sidor oraz Jewhen Zupan, twierdzą, że ruch, któremu przewodzą nie domaga się niepodległości, tylko realnej autonomii, jaką posiada Krym. Rusińscy separatyści nie zaprzeczają pogłoskom, że Moskwa sprzyja ich działaniom. Są one jednak realizowane w sposób dyskretny, aby nie przynosiło to reperkusji na forum międzynarodowym. Interesujący reportaż o sytuacji politycznej w obwodzie zakarpackim wraz z wywiadami przeprowadzonymi z organizatorami II Kongresu Rusinów 
Zażądano uznania obwodu zakarpackiego za region autonomiczny. W przeciwnym razie zapowiedziano oficjalne proklamowanie 1 grudnia 2008 r. niepodległości Zakarpacia. Służba Bezpieczeństwa Ukrainy zareagowała dość spokojnie na to ultimatum. Sprawdzono jedynie kwestie finansowe kongresu i przeprowadzono kilka przesłuchań. Oświadczono przez media, że tego typu separatystyczne apele nie stanowią specjalnego zagrożenia dla integralności państwa ukraińskiego. W zapowiadanym dniu żadnej proklamacji nie było a mieszkańcy obwodu zignorowali postanowienia kongresu.

Wszystkie te fakty świadczą, że sytuacja w obwodzie zakarpackim jest w miarę stabilna i nie grozi nieoczekiwanymi konsekwencjami o charakterze politycznym, a tym bardzie geopolitycznym ${ }^{25}$. Niewątpliwie ludność Zakarpacia czuje swoją odrębność i na pewno jest zainteresowana uzyskaniem terytorialnej autonomii. To jednak jest za mało aby wywołać zamęt lub destabilizację.

Warunki wewnętrzne są w miarę stabilne. Tego nie można jednak powiedzieć o uwarunkowaniach zewnętrznych, a zwłaszcza o relacjach jakie zachodziły na linii Kijów-Moskwa. Wiadomo, że władze rosyjskie popierają wszelkie tendencje odśrodkowe, które pojawiają się w państwie ukraińskim. Wszelkie tego rodzaju ruchy separatystyczne są traktowane przychylnie, gdyż osłabiają spoistość i zachodnioeuropejskie aspiracje Ukrainy. Dlatego też domaganie się przez obwód zakarpacki, nawet werbalnie, autonomii i większej niezależności może stanowić niebezpieczny precedens dla innych regionów Ukrainy. Procesy dezintegracyjne raz uruchomione kierują się swoistą logiką i nie zawsze są sterowalne. We wschodniej Ukrainie oraz na Krymie istnieją potężne siły polityczne zainteresowane "federalizacją", względnie nawet odłączeniem się od Ukrainy. Mają one wsparcie ze strony Federacji Rosyjskiej. Z tego powodu władze w Kijowie nie mogą sobie pozwolić na ryzykowne eksperymenty kwestionujące unitarność terytorialną państwa ukraińskiego. Z tego powodu wszelkie próby podważające istniejący status quo muszą być unicestwione w zarodku, gdyż istnieje zawsze ryzyko, że wymkną się spod kontroli. Władze centralne zdają sobie sprawę, że nie ma analogii do tego co się może wydarzyć na Zakarpaciu, w odróżnieniu od tego co grozi państwu ukraińskiemu ze strony sił odśrodkowych działających na Krymie czy w Donbasie. Niemniej dla sit, które wspiera Moskwa Zakarpacie może być wygodnym poligonem sprawdzającym postawę Kijowa wobec prób tworzenia regionów autonomicznych. Brak ludności rosyjskiej lub zrusyfikowanej w obwodzie zakarpackim ogranicza możliwości ingerencyjne władz rosyjskich z drugiej jednak strony tworzy kamuflaż bezstronności, który też może ułatwiać działania odśrodkowe i dywersyjne.

Pomimo tych międzynarodowych uwikłań i słabości geopolitycznej Ukrainy w najbliższym czasie nie należy oczekiwać spektakularnych incydentów na Zakarpaciu. Ludność tu mieszkająca jest od stuleci przyzwyczajona do bierności. Nie jest w pełni przekonana o swojej odrębności narodowej. Bardziej jest zainteresowana poprawą warunków materialnych, niż mrzonkami związanymi ze statusem niepodległościowym Zakarpacia. Tyle, że jak uczy historia w tej dziedzinie mogą mieć zawsze miejsce nieoczekiwane zdarzenia. Postawy ideowe grup etnicznych nie zawsze są racjonalne i przewidywalne.

\section{$\cdots \cdots$}

w Munkaczu (Mukaczewie) został opublikowany na łamach „Nowej Europy Wschodniej” (Z. Szczerek 2009 s. 135-142).

25 Liczni polscy komentatorzy obserwujący bieżącą sytuację w obwodzie zakarpackim wiele piszą o dążeniach separatystycznych miejscowych mieszkańców. Same tytuły artykułów publicystycznych wskazują, że problem jest nabrzmiały i grozi poważnymi reperkusjami geopolitycznymi. Można wymienić kilka z nich: Zakarpacie - sny o niepodległości (A. Korniejenko, 2008), "Tuż przy polskiej granicy wybuchnie konflikt" (Z. Szczerek, 2008), Zakarpacie - ukraińska Osetia czy medialna beczka prochu (I. Jóźwiak, 2009). Pomijając sensacyjność tytułów sama treść wywodów autorskich wskazuje, że sytuacja daleka jest od dramatyzmu, a nawet przybiera postać groteskową. Wynika z tego, że nie należy oczekiwać wydarzeń o istotniejszych skutkach politycznych. 
Adamski Ł., 2008, Nacjonalizm jawny czy podświadomy? Kilka uwag z powodu Historii Ukrainy Paula Roberta Magocsiego, "Sprawy Narodowościowe”, nr 4, s. 90-99, Poznań.

Bohač A., 1932, Narodnosti v Podkarpatskie Rusi podle predbeznych vysledku sčitani lidu roku 1930, "Statistisky Oborz", R. XIII, nr 1/2, Praha.

Bruski J.J., 1995, Rusini Karpaccy - separatyzm czy przebudzenie narodowe? (Z genezy wspótczesnego rusinizmu), [w:] Wanatowicz M.W. (red.), Regionalizm a separatyzm - historia i wspótczesność, Wydawnictwo Uniwersytetu Śląskiego, s. 158-179, Katowice.

Duć-Fajfer H., 2003, Aleksander Duchnowycz a uniwersum symboliczne Łemków, "Płaj”, nr 27, s. 65-69, Warszawa.

Eberhardt P., 1994, Przemiany narodowościowe na Ukrainie XX wieku, Biblioteka „Obozu", Warszawa.

Jarnecki M., 2005, Droga do identyfikacji narodowej. Stosunki narodowościowe na Rusi Zakarpackiej w przededniu I wojny światowej i w okresie międzywojennym, "Sprawy Narodowościowe", z. 27, s. 101-118, Poznań.

Jordan P., Klemenčič M., 2004, Transcarpathia - Bridgehead or Periphery? Geopolitical and Economic Aspects and Perspectives of a Ukrainian Region, Peter Lang. Europäischer Verlag der Wissenschaften, Frankfurt am Main.

Jóźwiak I., 2009, Zakarpacie - ukraińska Osetia w Karpatach czy medialna beczka prochu, http://www.psz.pl (6 lipca 2009 r.).

Kocsis K., 2001, Ethnic Map of Present Territory of Transcarpathia (Subcarpathia), Geographical Research Institute, Budapest.

Kocsis K., Kocsis-Hodosi E., 1995, Hungarian Minorities in the Carpathian Basin, Matthias Corvinus Publishing, Toronto-Buffalo.

Kocsis K., Kocsis-Hodosi E., 1998, Ethnic Geography of the Hungarian Minorities in the Carpathian Basin, Geographical Research Institute, Budapest.

Kolberg O., 1970, Ruś Karpacka, T. 54, cz. I, Polskie Towarzystwo Ludoznawcze, Wroctaw, Poznań.

Končak W., Končak S., 1977, Nasielienije Zakarpatija za 100 liet. Statistiko-diemografičeskoje issliedowanije, Wišča Škola, Lviv.

Korniejenko A., 2008, Zakarpackie sny o niepodległości, „Przemyski Przegląd Kulturalny”, nr 2(9), s. 4-8, Przemyśl.

Macartney C.A., 1937, Hungary and Her Successors. The Treaty of Trianon and Its Consequences 1919-1937, Oxford University Press, London, New York.

Magocsi P.R., 1992, Karpato-Rusini: obecny status i perspektywy. Kto to są Rusini?, "Sprawy Międzynarodowe”, nr 7-12, s. 95-110, Warszawa.

Magocsi P.R., 1994, The Rusyn of Slovakia. An Historical Survey, Columbia University Press, New York.

Magocsi P.R., 1995, Historical Atlas of Central Europe, University of Washington Press, Seattle, London.

Magocsi P.R., Pop I., 2002, Encyclopedia of Rusyn History and Culture, University of Toronto, Toronto.

Mayer M., Magocsi P.R., Boris J., 1998, Rusyns of Hungary: Political and Social Developments 1860-1910, Columbia University Press, New York. 
Mazurek T., 2009, Charakter konfliktów transgranicznych między polskimi i słowiańskimi Rusinami. Przeszłość, Teraźniejszość, Przyszłość, „Prace Geograficzne”, nr 121, Kraków.

Pop I.I., 2003, Istoriografija istorii rusin i Podkarpatskoj Rusi, "Stowianowiedienije", No. 1, s. 57-72, Moskva.

Przeciszewski P., 2007, Ruś Karpacka - zapomniany kraj, „Więź”, nr 1, s. 111-121, Warszawa.

Puškaš A., 2006, Civilizacija i varvarstvo. Zakarpatie 1918-1945, Izd. „Evropa”, Moskwa.

Shandor V., 1997, Carpatho-Ukraine in the Twentieth Century: A Political and Legal History, Ukrainian Research Institute, Harvard University, Harvard.

Sterčo P., 1994, Karpato-Ukrainska Derżava. Do istorii vizvolnoj borotbi Karpatskich Ukrainciv u 1919-1939 rokach, Izd. "Za Vilnu Ukrainu”, Lviv.

Szczerek Z., 2008, Tuż przy polskiej granicy wybuchnie konflikt, http://fakty.interia.pl (9 grudnia 2008 r.).

Szczerek Z., 2009, Kraj widmo, „Nowa Europa Wschodnia”, nr 2(IV), s. 135-142, Wroctaw.

Szul R., 2009, Język, naród, państwo. Język jako zjawisko polityczne, Wydawnictwo Naukowe PWN, Warszawa.

Żurawski vel Grajewski P.P., 1995, Sprawa ukraińska na konferencji pokojowej w Paryżu w roku 1919, Wydawnictwo Naukowe Semper, Warszawa.

\section{NATIONALITY PROBLEMS OF TRANSCARPATHIA}

\section{Summary}

The article discusses ethnic diversity and the changes which took place in Transcarpathia in the 20th century. First, the author presents the historical background for a statistical-demographical analysis. He points to the peripheral location of the region and the fact that it often changed its political affiliation. Thus, for a period of almost a thousand years the province was included within the borders of Hungary; between 1919 and 1939 it became part of Czechoslovakia, and after a four-day long period of independence (14-18 March, 1939) it was again incorporated into Hungary between 1939 and 1945. After World War II it was part of a Soviet republic, and since 1991 it has been included in the independent state of Ukraine.

Each of these periods brought far-reaching demographic and ethnic consequences. The population of Transcarpathia consisted of Slavic people of Ruthenian origin, mostly Greek Catholics. The inhabitants of the province were subjected to Hungarian, Ukrainian, and Russian influences and believed in different options, such as pro-Ukrainian, pro-Russian, or separatist, i.e. Ruthenian. These issues are discussed in detail in the article and thoroughly interpreted by the author. He also points to the fact that the territory of Transcarpathia was inhabited by numerous ethnic minorities. The Hungarian minority has always been the most important, both in the past and in the present; today it is concentrated in the south of the province. In the past, Jews and Germans also constituted sizeable minorities, while Romanians and Slovaks were always of marginal significance here. The final part of the article presents the scale of the separatist tendencies which may have dangerous political consequences in the future.

Keywords: Trancarpathia, Rus, Ukrainians, minorities 